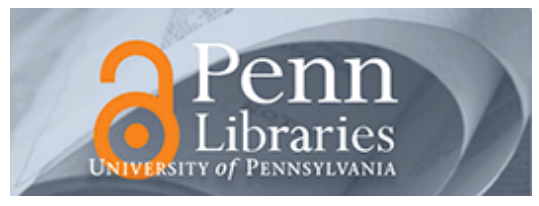

University of Pennsylvania ScholarlyCommons

$10-2007$

\title{
Taking a View: Corporate Speculation, Governance, and Compensation
}

Christopher C. Geczy

University of Pennsylvania

Bernadette A. Minton

Catherine M. Schrand

University of Pennsylvania

Follow this and additional works at: https://repository.upenn.edu/accounting_papers

Part of the Accounting Commons, and the Business Administration, Management, and Operations Commons

\section{Recommended Citation}

Geczy, C. C., Minton, B. A., \& Schrand, C. M. (2007). Taking a View: Corporate Speculation, Governance, and Compensation. The Journal of Finance, 62 (5), 2405-2443. http://dx.doi.org/10.1111/ j.1540-6261.2007.01279.x

This paper is posted at ScholarlyCommons. https://repository.upenn.edu/accounting_papers/45

For more information, please contact repository@pobox.upenn.edu. 


\title{
Taking a View: Corporate Speculation, Governance, and Compensation
}

\begin{abstract}
Using responses to a well-known confidential survey, we study corporations' use of derivatives to "take a view" on interest rate and currency movements. Characteristics of speculators suggest that perceived information and cost advantages lead them to take positions actively; that is, they do not speculate to increase risk by "betting the ranch." Speculating firms encourage managers to speculate through incentive-aligning compensation arrangements and bonding contracts, and they use derivatives-specific internal controls to manage potential abuse. Finally, we examine whether investors reading public corporate disclosures are able to identify firms that indicate speculating in the confidential survey; they are not.
\end{abstract}

Disciplines

Accounting | Business Administration, Management, and Operations 


\title{
Taking a View: \\ Corporate Speculation, Governance and Compensation
}

\author{
Christopher C. Géczy \\ University of Pennsylvania \\ Bernadette A. Minton \\ Ohio State University \\ Catherine Schrand \\ University of Pennsylvania*
}

Current draft: November 2005

\footnotetext{
* Correspondence to Christopher Geczy, e-mail geczy@wharton.upenn.edu. The authors thank Gordon Bodnar, Richard Marston, and Regina Risnychok and the Weiss Center for International Financial Research at the Wharton School for access to survey data on derivatives use and for extensive administrative support; Rudi Fahlenbrach, Andrew Metrick and Geoff Tate for other data used in the paper; and Sam Byun, Myriam Chang, Wes Gray, Lisa Huong, Jiunjen Lim, Vicki Von Krause and Michelle Zhang for excellent research assistance. We thank Bill Ahearn, Ramji Balakrishnan, Robin Greenwood and participants at the Western Finance Association meetings, Federal Reserve Bank of New York, University of North Carolina, University of Virginia (Darden), and University of Iowa for helpful comments and the Rodney L. White Center for Financial research for financial support. We gratefully acknowledge The Caesarea Center award.
} 


\section{ABSTRACT \\ Taking a view: Corporate speculation, governance and compensation}

Using responses to a well-known survey on derivatives use, this paper provides evidence on several aspects of the use of derivatives to "take a view" on interest rate and currency movements. Characteristics of the speculators suggest that they view speculation as a profitable activity because of information and cost advantages, and they trade accordingly. It does not appear that firms speculate to increase risk and exploit convexity in the firm's value function ("bet-the-ranch"). Firms that believe taking a view is valueenhancing encourage managers to engage in it (or at least do not discourage them from doing it) through incentive-aligning compensation arrangements and bonding contracts. Yet, firms use derivatives-specific internal controls to manage the potential abuse of the instruments. Finally, we examine whether investors using publicly available information in corporate disclosures could identify firms that openly admit to speculation in the confidential survey. The conclusion is that they cannot. 


\section{Taking a view: Corporate speculation, governance and compensation}

\section{Introduction}

Derivative instruments can be used to hedge market risk exposures, where "hedging" generally implies that the position is taken with the intention of reducing risk. Derivatives also can be used to speculate on movements in the value of the underlying asset. "Speculating" generally implies that the derivative position is undertaken with the primary intention of making a profit or increasing risk. While extant theoretical and empirical academic literature has advanced our understanding about why firms should and do use derivatives to hedge, ${ }^{1}$ relatively little is known about corporate speculation with derivatives. It has a pejorative connotation in the financial press, likely because of coverage about losses at firms such as Banc One, Proctor and Gamble, and Gibson Greetings. Yet it is not clear that this reputation is deserved. Is speculation an activity that is optimal ex ante and for which we would expect to observe some large negative outcomes ex post? Or, is it evidence of an agency problem and governance failure - an activity that in expectation will decrease expected shareholder value to the benefit of agents of the firm?

Survey data provide a basis for the analysis of the use of derivatives for speculation. The 1998 Wharton School/CIBC Wood Gundy survey asked respondents: "How often does your market view of [exchange or interest] rates cause you to actively take positions?" Possible responses are "Frequently," "Sometimes," or "Never." We define firms that respond "Frequently" as speculators. The survey's definition of speculation has two important features. First, it is the active use of derivative instruments and the decision to take positions is based on a market view. This activity is consistent with the type of speculation that concerns regulators and the public. Second, the survey question does not use the word speculation; it describes taking a view without an explicit or implicit

\footnotetext{
${ }^{1}$ See Stulz (2003) for a summary of this research.
} 
judgment about whether it is good or bad. Using the survey to define speculators, we are able to provide a detailed analysis of a variety of their characteristics including financial characteristics, compensation arrangements, governance mechanisms, internal controls, and financial statement disclosures.

The primary distinguishing financial characteristics of the firms that frequently speculate, conditional on using derivatives, are low leverage and high market capitalization. Firms specialize in their trading activities in areas in which they might have an information advantage. The firms that frequently speculate on foreign currency $(\mathrm{FX})$ rates have a greater percentage of operating revenues and costs denominated in foreign currency. Their FX hedging activities suggest that they also have significant tangible operations located in foreign countries, which could provide a source of expertise in the currency. The extensiveness of FX operations, however, does not explain speculation with interest rate (IR) instruments. The IR speculators are more extensively involved in various IR-related hedging activities relative to the non-speculators. There is no significant overlap between the firms that frequently speculate with currency derivatives and interest rate derivatives.

Taken together, these characteristics of speculators are consistent with the following scenario. Firms are motivated to use derivative instruments to hedge. Once the fixed costs of a derivatives operation are in place, however, some firms extend their derivatives program to include speculation. The firms that start speculating have (or believe they have) a comparative information advantage relative to the market such that they view speculation as a positive NPV activity. The large size of the speculators and their experience trading in the underlying could also suggest that speculators merely have a cost advantage and can engage in profitable arbitrage. Recall, however, that the survey question specifically defines speculation as trading based on a market view and that the sample consists only of firms that use derivatives. Thus, the sample substantially holds constant the fixed costs of trading. While there likely are some firms that have a cost advantage, and this advantage 
plays a role in their speculation decisions, it appears that firms believe an information-based decision can lead to profitable speculation and this belief, at least in part, influences their decisions to speculate.

The analysis of financial characteristics yields no evidence that the frequent speculators have incentives to "bet-the-ranch" due to a convex investment opportunity set (e.g., Campbell and Kracaw, 1999). The firm characteristics that measure incentives to increase convexity, however, are significantly associated with other proxies for potential risk-seeking activities of the sample firms lower diversification and higher stock return volatility. Thus, while the sample firms that we identify as risk-seekers engage in other risk-seeking activities, they do not seem to consider actively taking positions in derivatives based on a market view as similarly risk-seeking.

Compensation incentives of both the $\mathrm{CEO}$ and the $\mathrm{CFO}$ are related to cross-sectional variation in the frequency of speculation. In the survey, the speculators more often report that the derivatives function is benchmarked based on profits and not on risk-management effects. In addition, the CFO's stock price sensitivity (delta) is positively associated with the probability of actively taking positions, but the convexity of his options (vega) is not. The equity-based compensation of the CEOs, however, has the opposite association with speculation. Taken together, these results are consistent with the notion that the $\mathrm{CFO}$, not the $\mathrm{CEO}$, is the executive that acts on the compensation-related incentives and that speculator-firm CFOs view speculation as a profit-making activity. The CEOs at these firms, however, do not impede speculation.

Frequent speculators exhibit weaker wide-ranging governance mechanisms, but they monitor derivatives more carefully with tailored internal controls. Greater managerial power measured by the Gompers, Ishii, and Metrick (GIM, 2003) governance index is positively associated with frequent speculation. These results are particularly strong for firms that rely less on the market for corporate control as an ex post monitoring mechanism to prevent excessive risk-taking. Weaker monitoring in this general sense is associated with greater speculation. The speculating firms, however, have more 
frequent and scheduled reports of their activities to the Board of Directors, more sophisticated methods of and more frequent valuation, and stated policies that limit counterparty risk.

Finally, we show that market participants could not have discerned the activities of the frequent speculators from publicly available documents (e.g., 10-K filings). This result is not necessarily evidence of accounting fraud because speculation, as we have defined it, may not meet the requirements for reporting under generally accepted accounting principles (GAAP). Nonetheless, irrespective of whether we do not observe disclosure because the accounting rules do not require it or because firms are not implementing the rules properly, the end result is that the financial statements do not provide an accurate picture of the firm's speculative activities. These findings are important on their own accord given the recent rash of corporate scandals related to the financial reporting of offbalance sheet assets. They also substantiate the use of survey data as an appropriate vehicle to examine speculation.

Empirical evidence on whether speculation is an economically significant activity that warrants investigation is mixed. Some researchers conclude that the significance is modest based on either indirect evidence that derivatives appear to be used primarily for hedging (Hentschel and Kothari, 2001; Allayannis and Weston, 2001), or based on mean and median measures of the extent of derivatives use in general and not speculation per se (Guay and Kothari, 2003). Other researchers, however, document extensive use of the instruments for speculation specifically within the goldmining industry (Adam and Fernando, 2005; Brown, Crabb, and Haushaulter, 2003). The important measure of the significance of speculation, however, may be the lower tail of the distribution - the extent to which large negative outcomes can occur albeit with small probability. An analysis of securities litigation specifically associated with speculation confirms that such extreme values do 
occur and that they can have a significant impact on the firm's operations. ${ }^{2}$ The fact that speculative activities can have a material impact on the firm, albeit with low probability, coupled with the fact that these activities are generally unobservable and outside the core business of the firm - and thus unforeseen - increase the importance of examining speculation.

The paper is organized as follows. Section II discusses the survey, including its definition of speculation, and describes the survey respondents. Section III summarizes financial characteristics of speculators and the nature of their derivatives-related activities. Section IV describes compensation of the speculators and Section V summarizes their governance characteristics including internal controls. Section VI provides a review of financial disclosures of derivatives activities by the survey respondents. Section VII concludes.

\section{The survey and its definition of speculation}

Data on speculation are from a confidential survey on derivatives use. The use of a survey is imperative because, as we document in Section VI, publicly available information in financial statements is inadequate to ascertain whether a firm is engaging in speculative activities. The survey was co-conducted by the Weiss Center for International Financial Research at The Wharton School and CIBC World Markets. ${ }^{3}$ The survey instrument was sent to 1,928 publicly-traded non-financial firms in October 1997 with a second mailing in March 1998. ${ }^{4}$ The 1998 survey was the third survey of its type. As such, we expect that the respondents understand the questions and have sufficient

\footnotetext{
${ }^{2}$ Since passage of the Private Securities Litigation Reform Act of 1995 through the fourth quarter of 2000, there were four securities fraud cases that involved speculation: 1) Plains All American Pipeline; 2) Ashanti Goldfields Co.; 3) Fruit of the Loom; and 4) Avista Corporation. The alleged losses ranged from \$20 million to over \$400 million.

${ }^{3}$ The survey is included in its entirety in Appendix A. Bodnar, Hayt, and Marston (1999a, 1999b) present response tallies and tabulate and describe the basic results.

${ }^{4}$ The firms were randomly selected from the Compustat database of non-financial firms in 1994 to receive a similar survey. The sponsors updated the sample for the 1998 survey to include Fortune 500 firms that had not been selected in 1994 and to adjust for buyouts, mergers, and bankruptcies since 1994.
} 
knowledge to answer them, although we do not know the name or position of the person that completed the survey.

There were 366 usable responses, which represents a 19\% response rate. This response rate is greater than that for other surveys of corporate financial officers (e.g., 9\% in Graham and Harvey, 2001, and 12\% in Trahan and Gitman, 1995). Our sample consists of 341 of the 366 respondents. $^{5}$ The non-respondent sample has 1,047 firms after eliminating those with missing Compustat data.

\section{[Insert Table I here]}

Table I shows that of the 341 sample respondents, 186 report using derivatives in response to the first survey question: "Does your firm use derivatives (forwards, futures, options, swaps)?” Of these 186, 161 and 157 report using currency and interest rate derivatives, respectively. Overall, the industry membership of the respondent sample is representative of the Compustat population. There is no industry concentration of the frequent speculators. ${ }^{6}$

We use questions 12 and $15 \mathrm{~b}$ to identify the extensiveness of a firm's speculative activities. These questions asked the following separately for FX and IR derivatives use:

How often does your market view of exchange rates [interest rates] cause you to...

a. Alter the timing of hedges?

b. Alter the size of hedges?

c. Actively take positions?

Possible responses are "Frequently," "Sometimes," or "Never."

\footnotetext{
${ }^{5}$ Eighteen firms are eliminated because the firms engaged in a merger after the survey was sent but before the end of fiscal year 1997. It is not clear whether the pre-merger or post-merger entity completed the survey. Seven additional respondents are excluded because share price data are not available, and the equity incentives for these firms are not clear (five wholly-owned subsidiaries, one firm that is not publicly traded, and one co-op).

${ }^{6}$ We cannot disclose the exact industries of this group because of confidentiality.
} 
We define a firm as a speculator based on its response to part c. Part c of this question has two attributes that make it a reasonable definition of speculation. First, the word "active" is important. The active voice does not allow for confusion about whether not hedging is a form of speculation. Second, the question specifically indicates that the cause for taking positions is a market view. Thus, this activity is distinct from frequent trading that is due purely to a transaction cost advantage (e.g., arbitrage) without a view.

We define frequent (sometimes) \{non $\}$ speculators as those respondents that frequently (sometimes) \{never\} actively take positions based on a market view of either FX rates or interest rates (part c). There are 102 firms that never speculate, 61 that sometimes speculate, and 13 that frequently speculate. ${ }^{7}$ Because "sometimes" can capture a wide range of frequencies, we examine the robustness of our results to an alternative rule to classify the firms that sometimes take positions. Firms that sometimes actively take positions and that evaluate the risk management function by reduced volatility relative to a benchmark (question 21a) are classified as non-speculators. The remaining firms that sometimes take positions are classified as speculators. The logic is that if a manager's activities are consistent with the basis on which she is evaluated, then the meaning of "sometimes" should be less frequent for the firms that evaluate risk management based on reduced volatility. This classification of derivative users moves 34 firms from the sometimes category, which ceases to exist, to the speculator group, and moves 23 firms from the sometimes category to the non-speculator group. The results throughout the paper are robust to this alternative specification.

We define speculators based only on their responses to part $\mathrm{c}$ - actively taking positions - and not on their responses to parts $\mathrm{a}$ and $\mathrm{b}$ (altering the timing or size of hedges). Parts $\mathrm{a}$ and $\mathrm{b}$ use the

\footnotetext{
${ }^{7}$ The group of 102 firms that never speculate includes firms that never speculate with both FX and interest rate derivatives, or never speculate with one type of instrument and did not answer the question for the other instrument. The 61 firms in the "sometimes" speculate group responded that they sometimes actively take positions in both FX and interest rate derivatives, or sometimes speculate with one type of instrument and did not answer the question for the other instrument or never speculated with the other. There are 13 firms that frequently actively take positions in either FX or interest rate derivatives. The remaining nine firms of the 185 that answered that they use derivatives did not answer survey questions $12 \mathrm{c}$ and $15 \mathrm{bc}$ about actively taking positions based on a market view of exchange rates and interest rates, respectively.
} 
word "hedges" to describe the activity, which might suggest to survey respondents that this activity is part of a hedging program. Discriminate validity analysis confirms that survey respondents that actively take positions are distinct from those that alter the timing or size of hedges (parts a and b), which suggests that the use of part c only is appropriate. Of the firms that frequently alter the timing of their hedges, $67 \%$ also frequently alter the size of their hedges, while only $39 \%(44 \%)$ of the firms that frequently alter the timing (size) of their hedges also frequently actively take positions. ${ }^{8}$ In addition, firms' answers to part c, but not to parts a and b, are more consistent with their answers to survey question 21 , which asks how the firm evaluates its risk management function. When we use “actively taking positions" as the definition of speculation, almost $92 \%$ of the frequent speculators evaluate the risk management function based on profits (either absolute, relative to a bench-mark, or risk-adjusted), while only 54\% (60\%) of the non-speculators (sometimes speculators) use profit-based benchmarks. In contrast, if we were to define speculation as altering the timing (size) of hedges, $71 \%$ (79\%) of the frequent speculators would be evaluated by profit-based metrics. ${ }^{9}$

Using part c to define speculation also has convergent validity: Firms' answers to part c are consistent with their answers to other survey questions that concord with our intuition about how speculators use derivatives. Of the firms that frequently actively take positions based on market views, $46.2 \%$ frequently reduce costs or lock-in rates based on a market view and $15.4 \%$ respond that they never do so (Question 15a, part d). In contrast, only $2.5 \%$ of the non-speculators frequently reduce costs or lock-in rates based on market views while $52.5 \%$ say they never do so (both significantly different from frequent speculators at the $1 \%$ and $5 \%$ levels, respectively). In addition,

\footnotetext{
${ }^{8}$ Cronbach's alpha for the set of answers to parts a and b is 0.82 , versus 0.52 for the set of answers to parts a and $\mathrm{c}$ and 0.48 for the set of answers to parts $\mathrm{b}$ and $\mathrm{c}$.

${ }^{9}$ When we define profit-based metrics to include profits that are absolute, relative to a benchmark, or risk-adjusted, Cronbach's alpha for the set of answers to part c (actively taking positions) and question 21 is 0.28 . It is negative for the set of answers to question 21 and parts a and b (computed separately). The negative alpha suggests that respondents' answers to these questions are not ordered in the same conceptual direction. Defining profit-based metrics to include profits that are either absolute or relative to a benchmark, but not risk-adjusted, Cronbach's alpha for the set of answers to part $\mathrm{c}$ and question 21 is 0.42 , versus 0.08 for the set of answers to part a and question 21 , and 0.11 for the set of answers to part $\mathrm{b}$ and question 21 .
} 
$16.7 \%$ of the frequent speculators frequently transact in the currency derivatives market to arbitrage borrowing rates across currencies (Question 9) whereas only $2.5 \%$ of the non-speculators report doing so (the difference in means is significant at better than the $5 \%$ level).

The frequent speculators also report greater concern about market risk and monitoring of derivatives results. Of the frequent speculators, $61.5 \%$ express high concern about market risk with respect to their derivative activities (Question 4a, part c) while only $26.7 \%$ of non-speculators express the same level of concern, and the difference is statistically significant at the $5 \%$ level or better. None (7.7\%) of the frequent speculators have no (low) concern, compared to $8.9 \%(33.7 \%)$ for the nonspeculators. The majority (53.8\%) of the frequent speculators has high concern about monitoring and evaluating hedge results (Question 4a, part d) compared to only $24.8 \%$ of the non-speculators, a difference that is statistically significant at the $5 \%$ level. In contrast, $7.7 \%$ of the frequent speculators indicate no or low concern about monitoring and evaluating hedge results while $34.7 \%$ of the nonspeculators have no or low concern.

As in any study that uses survey data, the potential impact of non-response bias must be assessed. If firms did not respond to the survey due to a lack of interest, which is most likely if they do not use derivatives, then non-response does not create a bias given that our sample consists only of derivatives users. If however, the non-respondents are firms that actively take positions and believe their activity to be viewed unfavorably, then non-response creates a bias in that derivatives use by the non-respondents is likely different from derivative use by the respondents.

Several factors suggest that the non-respondents are most likely to be simply uninterested nonusers of derivatives that do not create a significant bias concern. First, the survey is about derivatives use, in general, which is not pejorative; it is not about speculation per se. Also, firms were given assurance that highly limited access would be granted to their responses. This assurance and the limited focus on speculation mitigates concerns that firms did not respond to the survey because they 
believed their use of derivatives would be viewed unfavorably.

Second, the respondents are significantly larger than the non-respondents and prior research has shown a correlation between firm size and derivatives use (Stulz, 2003). As reported in Table I, the average book value of total assets for the responding firms is $\$ 6,028$ million compared to $\$ 2,663$ million for non-responding firms. The average market value of the firm (SIZE), which is defined as the sum of the market value of equity, the book value of long-term debt, and the book value of preferred stock, is $\$ 8,523$ for the responding firms versus $\$ 4,241$ for the non-responding firms. ${ }^{10}$ The averages and medians are statistically different for all three size measures.

Third, the early responders seem to be "more interested" derivatives users than the late responders, which (subjectively) implies that response timing, and by implication non-response, are related to interest in the survey topic (Armstrong and Overton, 1977). ${ }^{11}$ Of the early responders, 55\% are derivatives users compared to $48 \%$ of the late responders. More importantly, ten of the 13 frequent speculators $(77 \%)$ were early responders, which suggests that these firms did not avoid the survey, but rather expressed interest. Thus, non-response bias should not affect our inferences.

\section{Financial characteristics of speculators and their activities}

This section characterizes the firms that use derivatives to speculate. The sample includes only the 186 survey respondents that use derivatives. The cost of speculating has a variable cost component, but it also has a significant fixed cost component related to maintaining personnel and equipment (Nance, Smith, and Smithson, 1993). If these fixed costs also relate to a firm's hedging

\footnotetext{
${ }^{10}$ Share price data for one firm traded on the OTC bulletin Board are from Bloomberg for the closest date to the firm's fiscal year end, which was within one week. For a firm with three tracking stocks, SIZE is the sum of the market values of the three separate tracking stocks and the book value of long-term debt, and the book value of preferred stock.

${ }^{11}$ The survey was sent in October, 1997 . We define early responders as the $62 \%$ of the surveyed firms that responded by the end of 1997 (97\% were received by November 17). The "late" responders are firms that responded after the second mailing in March 1998. The latest response was received May 22; 96\% of the late responses were received by April 28.
} 
activities, then conditioning the comparisons on derivatives use effectively holds constant the fixed costs of speculation. ${ }^{12}$

\section{A. Financial characteristics of the speculators}

Table II, Panel A, reports univariate statistics for financial characteristics across three groups: Firms that never speculate $(n=102)$, sometimes speculate $(n=61)$, and frequently speculate $(n=13)$. Theoretical explanations for optimal speculation motivate the variables that we examine (e.g., Smith and Stulz, 1985; Campbell and Kracaw, 1999; Adam, DasGupta, and Titman, 2004). Appendix B describes the computation of the variables used throughout the paper.

[Insert Table II here.]

The frequent speculators are significantly larger than the sometimes speculators, and larger (but not significantly) than the firms that never take a view. Firm size (SIZE) is the natural log of the market value of the firm, which is defined as the sum of the market value of equity, the book value of long-term debt, and the book value of preferred stock. The groups, however, are not significantly different in terms of industry-adjusted size relative to the median firm in the industry (I-SIZE).

The frequent speculators have significantly higher average growth opportunities than firms that never or sometimes speculate based on the book-to-market ratio as a measure of growth opportunities, ${ }^{13}$ but they are not significantly different on the basis of their R\&D expenditures.

\footnotetext{
12 The non-users are significantly different from the derivatives users; the differences are consistent with the results documented in Geczy, Minton and Schrand (1997). In results not reported, we repeat the multinomial logit analysis with four categories: $0=$ no derivatives use; $1=$ derivatives use but never takes a view; $2=$ sometimes takes a view; and $3=$ frequently takes a view. The results are consistent with those reported in Tables II, IV and VI.

${ }^{13}$ The tabulated results exclude one non-speculator firm that has a negative book-to-market ratio in 1995 due to negative book equity but positive ratios in 1996 and 1997, and an overall negative average ratio over the three years.
} 
Evidence of differences in solvency is mixed. ${ }^{14}$ The groups of firms do not differ statistically on the basis of short-term liquidity as measured by the quick ratio (QUICK), defined as cash and short-term investments divided by current liabilities. The frequent speculators have significantly lower long-term debt ratios, which could indicate better long-term solvency. However, differences in debt ratings and interest coverage ratios (COV) across the groups are insignificant.

In Panel B, we report estimates of the association between speculation and firm-specific financial characteristics from a multinomial logit (MNL) analysis. The dependent variable categories are that a firm never, sometimes, or frequently takes a view. The independent variables are the bookto-market ratio, SIZE, the quick ratio, and the debt-to-equity ratio. ${ }^{15}$ These variables represent one proxy for growth/investment opportunities, firm size, short-term liquidity and long-term solvency. Results using the other proxies for these constructs yield highly similar results.

Consistent with the univariate analysis, the only financial characteristics that emerge as significant covariates with speculation are firm size (+) and the DE ratio (-). The frequent speculators and the firms that never speculate are significantly larger than the firms that sometimes take a view. The non-speculators have higher debt-to-equity ratios (marginal probability is $0.6659, \mathrm{p}$-value $=$ 0.0068), while debt-to-equity ratios are negatively associated with the probability of sometimes speculating (p-value of 0.0511) and of frequent speculation (p-value of 0.0434$)$.

$\underline{\text { Stulz (1996) }}$ suggests one interpretation of the negative association between DE ratios and speculation. He contends that financial distress can mitigate other incentives to speculate because

\footnotetext{
${ }^{14} \mathrm{We}$ include commonly-used liquidity ratios in the table. We examine a variety of other liquidity metrics, and the conclusions are the same. Following Lamont, Polk, and Saá-Requejo (2001), we calculate a large sample version of Kaplan and Zingales' (1997) measure of financial constraint for each firm (KZ) and an industry-adjusted KZ measure using three-digit SIC codes. Following Geczy, Minton, and Schrand (1997, 1999), we create an industry-adjusted S\&P bond rating that increases with decreasing bond ratings. We create six variables that are versions of free cash flow, defined as operating cash flow less required investment, which is a combined measure of financial constraint and efficient scale. The proxies for operating cash flow and required investment include various combinations of net cash flow from operating activities, net cash flow from financing activities, share repurchases, cash dividends, cash flows from sales of PPE, capital expenditures, and net acquisition costs. The resulting variables are scaled by firm size (SIZE). The six measures are industry-adjusted relative to the median firm in the firm's three-digit SIC industry.

${ }^{15}$ Firms' quick ratios and D/E ratios are negatively correlated (-0.2982).
} 
distressed firms are less likely to be able to sustain an ex post negative outcome. If higher DE ratios are an indication of distress, then firms with higher DE ratios are less likely to speculate, ceteris paribus. Of course, an equilibrium view of DE ratios might suggest that firms have high debt ratios because they can and it is optimal to do so, irrespective of their level of financial distress. Since firm size can proxy for a number of firm attributes and incentives, we provide no interpretation of the positive association between firm size and speculation at this point in the paper, but we will return to this result later.

The patterns in the financial characteristics of the speculators are not consistent with "bet-theranch" theories of speculation, in which it is optimal for a firm that faces a convex investment function to speculate (e.g., Campbell and Kracaw, 1999; Adam, DasGupta, and Titman, 2004). These theories suggest that speculators should have 1) good growth opportunities, 2) a low efficient scale endowment, 3) low short-term liquidity, and 4) high costs of external finance. We find no evidence of a relation between speculation and either growth opportunities, as measured by book-to-market ratios or research and development expenditures, or short-term liquidity, measured by the quick ratio. Speculation also is not associated with industry-adjusted firm size as a measure of efficient scale. The better solvency of the frequent speculators contrasts with predictions from the convexity theories that predict that speculators would have a higher cost of accessing external debt capital, ceteris paribus.

\section{B. Speculation and other firm activities}

We report three key findings about the association between speculation frequency and a firm's involvement in other risk-related activities. The first finding is that frequent speculators have greater ex ante exposure to the underlying rate. Firms that frequently speculate on FX rates have a greater percentage of operating revenues and costs denominated in foreign currencies relative to firms that never or sometimes actively take positions (Table III, Panel A). There is, however, no such pattern for 
the firms when categorized based on the frequency of their use of IR instruments (Panel B). The hedging activities of the firms that frequently speculate on FX rates suggest that they are not simply making purchases and sales in foreign markets, but that they have operations located in foreign countries. Specifically, they are more likely to hedge foreign repatriations and translation of foreign accounting statements than firms that sometimes or never speculate with foreign currency instruments (Question 9). The IR speculators are more extensively involved in all types of IR-related hedging activities: They are more likely to swap from floating rate to fixed rate debt, fix rates on new debt issues in advance, and lock in rates (Question 15a).

[Insert Table III here.]

The second finding is that firms that take a view using currency derivatives do not always frequently take active positions in interest rate derivatives. Two-thirds of the FX speculators report that they only sometimes take positions in interest-rate derivatives (not tabulated).

The third finding is that speculation with derivatives appears to be a distinct activity from other "risk-seeking" activities. Following Coles, Daniel and Naveen (2004), we measure risk taking as firm focus, or a lack of diversification. The two proxies for firm focus are: 1) a Herfindahl index of a firm's concentration of sales in reportable segments, which is the segment sales from the largest segment (in terms of sales) divided by total firm sales in $1997,{ }^{16}$ and 2 ) the number of reported segments at year end 1997. Fewer segments and higher concentration ratios suggest a type of equilibrium risk-seeking behavior. We also consider return volatility (RETVOL) as an ex post summary measure of risk-taking following Agrawal and Mandelker (1987) and DeFusco, Johnson, and Zorn (1990). RETVOL is the standard deviation of daily returns for 1997 from CRSP.

\footnotetext{
${ }^{16}$ We use the number of segments reported in 1997 under the segment accounting rules existing at the time. We do not use the number of segments reported for 1997 in the 1999 annual report under SFAS 131.
} 
Table III, Panel C, reports that there are no statistically significant differences in firm focus across frequency of speculation. Thus, the firms that choose to speculate with derivatives do not also take risks through lower diversification. In addition, frequent speculators have significantly lower return volatility than the non-speculators and sometimes speculators. This pattern is opposite the pattern expected were speculation with derivatives an activity complementary to other risk-seeking activities captured by RETVOL.

Moreover, when we classify the firms as low, moderate, and high risk-takers based on each of the three measures of risk-taking (two proxies for firm focus and RETVOL), we find that the high risk-takers are smaller, have higher R\&D expenditures, and worse S\&P bond ratings than the low risktakers (results not tabulated). These results indicate that measures of convex incentives, which as previously documented are not associated with speculation, are correlated with greater risk-taking in activities other than derivatives use and support the conclusion that speculators are not responding to the driving incentives of the "bet-the-ranch" theories of speculation.

\section{Conclusions}

The analysis thus far indicates that speculators: 1) Are larger than non-speculators; 2) Tend to specialize in either FX or IR instruments, and the specialization is correlated with the extent and nature of the firm's exposure to the underlying; 3) Have low leverage; 4) Do not differ from non-speculators with respect to incentives to increase risk; and 5) Do not engage in other examined risk-seeking activities to a greater extent that non-speculators.

One explanation for speculation that is consistent with these findings taken together is that firms speculate because they believe it to be a profitable activity and not an intentionally risk-seeking activity that merely provides upside potential. Firms might expect speculation to be profitable under two conditions: 1) if the firm believes it has superior information about FX or IR rates (Stulz, 1996), 
or 2) if it has a transactions cost advantage in trading. Our results cannot distinguish these two explanations, and both likely explain speculation to some extent. In assessing the relative plausibility of these explanations, we bear in mind the following. First, the survey specifically asks about taking positions "based on a market view." The information advantage story requires a market view; a transactions cost advantage story does not. Second, firms tend to specialize in FX or IR trading, and they specialize in activities in which it is possible for the firm to believe it has an information advantage. However, economies of scale that generate a transactions cost advantage also could be specific to an underlying. Finally, the sample is conditioned on derivatives use. While firm size might be correlated with a transaction cost advantage in an unconditional sample because firm size is correlated with derivatives use, the evidence that size is correlated with speculation favors the transactions cost story less in our conditional sample.

Responses to a follow-up survey also suggest that frequent speculators' decisions to speculate are predicated, at least in part, on beliefs in an information advantage. ${ }^{17}$ Respondents indicate that their perceived sources of competitive advantage were largely associated with costs of leverage, informational advantages gained from government or official sources, informational advantages derived directly from trading in financial markets, and experience or skill in trading. Firm size/economies of scale, cost structure in the financial markets (execution costs, etc.) and informational advantages gained from operations like product sales were most frequently ranked lowest among all possible choices, including an open-ended "other" category.

The 1998 survey unfortunately provides no indication of whether speculators make profits on this activity as we would predict if they have an information advantage. Hence, we do not conclude that speculators actually have an information advantage in FX and IR markets. In fact, the information advantage theory is commonly used to explain speculative behavior in commodity markets; it seems

\footnotetext{
${ }^{17}$ The follow-up survey was sent to all respondents from the 1998 survey that are still in existence. Twenty-one of the firms responded, including five of the original frequent speculators and two firms that did not indicate any thing in the initial survey but reveal frequent speculation in the follow-up survey.
} 
less plausible that firms have an information advantage in interest rate and FX markets. Even for commodity markets (i.e., gold), however, empirical evidence suggests that the average profits of speculating may, ex post, be low (Adam and Fernando, 2005; Brown, Crabb, and Haushaulter, 2003). Nonetheless, the theory is not that the firm has a superior information advantage, only that it believes it has one. ${ }^{18}$

\section{Speculation and compensation}

This section reports on the relation between speculation and compensation for both the CEO and the CFO. The CFO is generally charged with all treasury operations including risk management functions (c.f., Graham and Harvey, 2001) at both the highest strategic levels and often at the operational level. Evidence from the follow-up survey also suggests that CFOs not CEOs make key decisions about speculation and are often solely responsible for forming a view that motivates derivatives positions.

\section{A. Equity-based incentives}

Many theoretical models make the intuitive prediction of a positive relation between optionbased compensation and incentives for managers to take risks because stock price volatility increases call option values (e.g., Smith and Stulz, 1985, specifically with respect to derivatives). Such models predict a positive association between the sensitivity of a manager's compensation to equity price volatility and speculation, even if speculation only increases the volatility of underlying firm value without a commensurate return to risk. There is some empirical evidence of a positive association between the sensitivity of a manager's compensation to: 1) general measures of firm risk such as return volatility or financial leverage (e.g., Agrawal and Mandelker, 1987; DeFusco, Johnson, and

\footnotetext{
${ }^{18}$ Jorion (1995) provides the following anecdote: "When asked, late in 1993, why he believed interest rates would remain low, Citron [Orange County Treasurer at the time of the derivatives debacle] replied: 'I am one of the largest investors in America. I know these things."”
} 
Zorn, 1990); 2) specific risk-taking activities other than derivatives use, such as higher investment in R\&D, less investment in property, plant and equipment, and more focus on fewer lines of business (e.g., Coles, Daniel and Naveen, 2004); or 3) investment in high-risk operating activities (e.g., oil and gas exploration in Rajgopal and Shevlin, 2002).

The empirical evidence, however, is not overwhelming and several recent papers question the conventional wisdom that executive stock options always provide incentives for increased risk-taking. Some models incorporate institutional aspects of executive behavior or of the markets for executive stock options (ESOs), which distinguish them from a liquidly-traded call option, and provide conditions under which ESOs do not provide incentives for increased risk-taking (see, for example, Carpenter, 2000). Ross (2004) shows how simply considering stock options as part of an executive's entire compensation package can lead to a prediction of a negative relation between option-based compensation and incentives to increase return volatility.

Existing empirical evidence related specifically to derivatives use and compensation is mixed. In cross-sectional studies across broad samples of firms, there is little evidence that the use of derivatives - for hedging or speculation - is greater for managers with more equity-sensitive compensation (see Geczy, Minton, and Schrand, 1997, among others). In the specific context of speculation, Brown, Crabb and Haushalter (2003) find no evidence that actively managed changes in the (gold market) hedge ratios of gold producers is connected to compensation proxies. There is, however, some early evidence of a positive association between not hedging with derivatives (as opposed to speculation) and compensation in industry-specific studies (see, for example, Tufano, 1996, and Schrand and Unal, 1998).

We analyze the association between speculation with derivative instruments and two features of a manager's equity-based compensation. Following Core and Guay (1999), DELTA and VEGA capture the sensitivity of a manager's wealth, received through compensation, to the outcomes of his 
decisions, in this case speculation. DELTA is the sum of the deltas for exercisable and unexercisable options plus the delta of the manager's current shareholdings, where delta is based on the BlackScholes option pricing formula as modified by Merton (1973) to account for dividend payouts. Thus, DELTA measures the sensitivity of the manager's firm-specific equity-based wealth to a $1 \%$ change in the firm's stock price. VEGA is the sum of the corresponding vegas and measures the sensitivity of the manager's wealth to a $1 \%$ change in firm stock return volatility.

\section{[Insert Table IV here.]}

Table IV, Panel A reports descriptive statistics of the compensation variables. The average wealth deltas of the CEOs range from 457.85 for the firms that sometimes speculate to 718.38 for the firms that never speculate. The average wealth deltas of the CFOs are significantly lower. The average vegas of the CEOs range from 90.47 for the firms that never speculate to 123.42 for the firms that frequently speculate. The vegas of the CFOs are again significantly lower. As a benchmark, the average delta for the Core and Guay (1999) sample of 5,352 CEO-year observations from 1992 to 1996 is 557.7 with a median of 117.4 and a standard deviation of 3,680.5.

Comparisons across the groups of speculators indicate that the CFOs of the frequent speculators (165.09) have statistically higher wealth deltas on average than those of the nonspeculators. The CFO vegas are also higher, but the difference is not statistically significant. The differences between DELTA and VEGA for the CEOs of the three groups are not significant. ${ }^{19}$ Multinomial logit estimations that include the compensation variables and SIZE and DE are in Panel B. The point estimates of marginal probabilities associated with SIZE and the debt to equity

\footnotetext{
${ }^{19}$ We also examine the ages and tenures of the CEOs and CFOs. The average CEO of frequent speculators has been at the firm longer than the CEOs of the non-speculators and firms that sometimes speculate, but there are no other distinct patterns. See Gibbons and Murphy (1992) and Yermack (1995), for example, for theories of the relation between executive age and tenure and equity-based incentives and Stulz (1996) as they might apply specifically to speculation.
} 
ratio remain essentially the same as those presented in Table II. However, the debt-to-equity ratio is no longer a significant determinant of the likelihood of frequent speculation at standard significance levels.

The incentives of both the CEO and the CFO are associated with a firm's choice to speculate but in opposite directions. ${ }^{20} \mathrm{CFO}$ wealth deltas have a positive marginal probability for frequent speculators ( $p$-value of 0.072). Thus, the CFOs whose wealth is most sensitive to changes in firm value are more likely to actively take positions based on a view of rates. CFO vegas are not significant. In contrast, CEO wealth deltas have a negative marginal effect for frequent speculators (pvalue of 0.058 ) and a positive marginal effect for non-speculators ( $p$-value of 0.059 percent). At the same time, CEO wealth vegas have a negative marginal probability for non-speculators and a positive marginal probability for sometimes speculators.

\section{B. Other compensation-related incentives}

Table V provides evidence on the relation between speculation and non-equity-based compensation. The average annual bonus of the $\mathrm{CEO}(\mathrm{CFO})$ for the sample firms is $\$ 782$ thousand $(\$ 235,000)$. Bonuses represent approximately 42\% (35\%) of a CEOs (CFOs) cash compensation. Table $\mathrm{V}$ reports that bonuses are a more significant percentage of cash compensation for the frequent speculators. The bonuses of the CFOs of frequent speculators are significantly greater than those of the firms that sometimes speculate.

[Insert Table V here.]

\footnotetext{
${ }^{20}$ The results are similar when the model is estimated including either the CEO or CFO variables but not both.
} 
The benchmarks the frequent speculators use to evaluate their derivatives activities are different than those of other firms, also reported in Table V. Related to interest rate exposure, for example, none of the frequent IR speculators (six firms) evaluate management of the debt portfolio based on the reduction in interest expense volatility, which is a hedging-related motive for using derivatives, compared to $15.9 \%$ and $10.2 \%$ of the non-speculators and sometimes speculators, respectively. The frequent speculators are more likely to evaluate management of the debt portfolio based on the impact on the cost of funds versus a benchmark. Related to foreign currency exposure, all of the firms that frequently speculate with FX derivatives (nine firms) use a benchmark and $44.4 \%$ $(22.2 \%)$ of them speculate based on spot rates (forward rates). By contrast, $34.8 \%(21.9 \%)$ of the firms that never (sometimes) speculate have no benchmark.

Behavioral explanations for firm decisions, especially overconfidence, are becoming commonplace (Heaton, 2002), and it may be natural to associate optimism (or overconfidence) with speculation based on having a market view on interest rates or foreign currencies. The results in Table $\mathrm{V}$, however, do not convincingly suggest that managerial "hubris" - in the spirit of Tate and Malmendier (TM, 2004) - is associated with the likelihood of speculation. The TM measure for hubris is an indictor variable that equals one if a CEO holds an option on his company's stock until expiration (LONGHOLDER). TM argue that it is generally suboptimal for a CEO to hold an option to maturity unless the CEO is overconfident. The proportions of the LONGHOLDER CEOs in the frequent, sometimes, and non-speculator samples are insignificantly different from one another, however, this result is based on a small sample and point estimates are increasing in frequency of taking a market view. ${ }^{21}$

\footnotetext{
${ }^{21}$ We have the TM hubris measure for only four of the frequent speculators and only for the CEO. Managerial hubris does not emerge as a significant correlate of the probability of using derivatives to speculate in the multivariate analysis.
} 


\section{Conclusions}

If the $\mathrm{CFO}$ is the agent who makes central decisions regarding actively taking positions, as suggested by our follow-up survey, then the positive association between speculation and CFO DELTAs and between performance-based bonuses and speculation, combined with, the lack of an association between speculation and CFO VEGAs suggests that CFOs of speculators, on average, view speculation as a positive NPV activity (Merton, 1973), ${ }^{22}$ as opposed to an activity that increases volatility but is either zero or negative NPV.

Responses to the follow-up survey indicate that the CFO is, in fact, likely the agent who makes central decisions regarding actively taking positions. For example, every speculator who answered our follow-up survey indicates that while the $\mathrm{CFO} /$ treasurer alone or staff within the financial function of the firm is responsible for forming views - and results are evaluated on the basis of absolute profit/loss (most common response) or increased profit (reduced costs) relative to a benchmark - in only one case are results of derivative use evaluated by the $\mathrm{CFO} /$ treasurer alone. Results are much more frequently evaluated by a risk committee or, to quote one respondent, "Executive Management."

The finding that the speculators' benchmark for FX derivatives is the item on which they are taking a view is consistent with the proposal that these firms speculate because they believe it to be a profitable activity, not merely a risk-seeking activity. If a manager believes she has superior knowledge about the spot rate and therefore can profit from this view, she would believe she can beat the benchmark and compensation benchmarks can be set accordingly.

\section{Speculation and governance mechanisms}

In the previous section, we analyzed the association between speculation and compensation contracts that can provide ex ante incentives to the decision-making agent. In this section, we examine

\footnotetext{
${ }^{22}$ See Murphy (1999) for a review of the extensive theoretical and empirical literature that links equity-based compensation to incentives for managerial decisions.
} 
the association between ex post monitoring and speculation. In Section A, we examine precommitment strategies for ex post monitoring of the manager in general, but not specifically with respect to derivatives use. In Section B, we examine internal controls which also are a precommitment device, but which firms can tailor to monitor derivatives use.

\section{A. General monitoring mechanisms}

We measure a firm's ex ante commitment to ex post monitoring with the Gompers, Ishii, and Metrick (GIM, 2003) governance index. GIM and Fahlenbrack (2004) categorize 24 charter provisions, bylaw provisions, and other firm-level rules associated with corporate governance into five types: (1) Tactics for delaying hostile bidders (DELAY), (2) voting rights, (3) director/officer protection, (4) other takeover defenses, and (5) state laws. Their overall index and the five component indices generally score one point for each provision that restricts shareholder rights or increases managerial power. ${ }^{23}$ Thus, a higher index score represents greater managerial power (weaker shareholder rights). We do not take a stand on whether a high index represents "good" or "bad" governance. We assume only that the index is negatively correlated with the use of mechanisms that can bond an agent to act in the principal's interest. The GIM index is available for 84 of the 102 nonspeculators, 47 of the 61 sometimes speculators, and 11 of the 13 frequent speculators.

Frequent speculators, on average, have higher GIM indices (more control in the hands of management) than firms that never speculate. The component of the index that measures provisions that allow managers to delay hostile takeovers (DELAY) varies from 2.07 for non-speculators to 2.91 for frequent speculators, a difference that is statistically significant at the 5\% level. The DELAY provisions include staggered or classified boards on which directors serve in staggered terms, blank check preferred stock over which a firm's current board has substantial authority, limitations on the

\footnotetext{
${ }^{23}$ GIM adjust their measure for various opt-out or opt-in choices firms have relative to state laws dictating certain governance behaviors. We make the same adjustments.
} 
ability to take action via written consent, and special meeting provisions limiting or eliminating the ability of shareholders to call special meetings (causing them to wait for regularly scheduled meetings to disengage takeover defenses). GIM note that legal scholars such as Coates (2000) and Daines and Klausner (2001) suggest that the provisions captured by DELAY render the other defenses redundant. There are no significant differences among the groups for the other four components.

\section{[Insert Table VI here.]}

Panel B reports results of multinomial logit estimations that include the governance variables and explanatory variables found to be significant in previous analyses. The results for SIZE and the DE ratio in general mimic those in Table II and the governance index emerges as an important explanatory variable. Its marginal probability for the frequent speculators is significantly positive (0.0118, p-value of 0.067), which suggests that speculating firms tend to be those whose shareholders have fewer rights.

The positive association between managerial power as measured by the GIM index and speculation is consistent with the negative relation between $\mathrm{DE}$ and speculation, if debt acts as a monitor of managerial behavior ((e.g., Harris and Raviv, 1979; Diamond, 1984; and Diamond, 1991, and others). . Assuming lower DE ratios imply less monitoring, the speculators have less monitoring by both creditors and takeover markets. While this result does not imply that all firms with weak corporate governance structures will speculate or which of the twenty-four provisions embodied in the governance index are most influential, it strongly suggests that managers who speculate have less concern about the disciplining nature of the market for corporate control.

In a separate regression, DELAY significantly influences the likelihood of frequent speculating versus not speculating. The coefficient on the DELAY component is negative for the non-speculators, 
although the $p$-value is not significant $(0.258)$. The relation between DELAY and frequent speculation is positive and significant ( $\mathrm{p}$-value of 0.048 ). Corporate governance, as measured by DELAY, also retains a strong relation with the frequency of speculation when we include the compensation variables in the model. The relationships between all of the explanatory variables and the likelihood of speculation are similar to those presented previously in terms of both magnitude and significance. The only exception is that the coefficient on SIZE for the frequent speculators is negative. However, like the estimates when just the compensation variables are in the model (Table IV) and when just the DELAY variable is in the model, it is not significantly different from zero. ${ }^{24}$

\section{B. Internal controls}

Table VII reports descriptive statistics about internal controls related to derivatives use.

Overall, the speculators exhibit greater oversight of derivatives activities as evidenced by four key differences between the firms that actively take positions based on market views and those that sometimes or never do. First, $100 \%$ of the speculators have a centralized approach to managing the firm's risk management activities. The percentage of firms that use a centralized approach is lower $(95 \%)$ for the firms that sometimes speculate and still lower $(89 \%)$ for those that never speculate. The International Organization of Securities Commissions (IOSCO, 1998) report on risk management and control guidance associated with derivatives use indicates that a centralized approach may be desirable; a decentralized approach may be ineffective especially for larger and more complex entities.

\footnotetext{
${ }^{24}$ Several of the results presented up to this point can be used to examine the predictions of Brown and Khokher (2001). A rather broad and somewhat indirect implication of their model is that firms may invoke a view of market prices that are correlated with their core (industry-related) competencies. Our analysis thus far generally supports a correlation between a firm's "expertise" and speculation. The Brown and Khokher model, however, also predicts a positive association between speculation and financial constraints as well as between speculation and managerial autonomy. The previously documented associations between leverage and speculation do not support this prediction. Moreover, the positive association between speculation and the GIM index, and in particular the DELAY component of it, is inconsistent with the prediction of Brown and Khokher (2001).
} 
[Insert Table VII here.]

Second, the speculators report activities to the Board of Directors (BOD) more frequently. Over $77 \%$ of the frequent speculators report derivatives activities to the BOD on a set schedule (monthly, quarterly, or annually). Firms that only sometimes take positions or never take positions report less frequently or have no set schedules. The greater centralization and more frequent reporting schedules of the speculators may also suggest that the speculators have more extensive and complicated derivatives activities in general that require such oversight.

Third, the frequent speculators deal with better counterparties on average. They never deal with counterparties rated $\mathrm{BBB}$ or lower, while between $1.9 \%$ and $3.6 \%$ of the sometimes speculators and between $6.7 \%$ and $10.5 \%$ of the firms that never speculate (depending on the instrument maturity) deal with BBB or lower counterparties. From an internal control perspective, the more important data are that between $11.3 \%$ and $14.3 \%$ of the firms that never or sometimes speculate have no set policy regarding counterparty risk. All of the frequent speculators report that they have a policy.

Finally, the frequent speculators differ from the firms that never or sometimes speculate with respect to portfolio valuation. The speculators more frequently value their portfolios. Almost onethird of the frequent speculators value their portfolios daily compared to only $8.5 \%$ and $19 \%$ of the sometimes and never speculators. The frequent speculators also are more likely to use an internal source or outside dealers to value the portfolio rather than the dealer that originated the transaction, as evidenced by the significantly lower mean scores for these variables. In addition, the frequent speculators are significantly more likely to calculate value at risk measures for some or all of their derivative portfolios. 


\section{Conclusions}

In summary, frequent speculators do not use contractual arrangements that bond them to stronger governance in general, at least as measured by the GIM index. But frequent speculators address the potential that agents will abuse derivatives and take "excessive" risks through the implementation of specific controls related to derivatives use. Internal controls, like bonding mechanisms, can reduce agency costs if a firm commits to them ex anteThe benefit of internal controls over more general contracting mechanisms, however, is that they can more readily be tailored to monitor specific actions in a timely and effective manner. This relative advantage is likely to be especially important for derivatives trading activities because of the frequency of the activity and the liquidity of the instruments relative to other activities such as capital investment decisions.

\section{Reporting of speculative activities}

We review the financial footnotes in 10-K filings at fiscal-year 1997 for the survey firms that frequently take a view on interest rates or currency movements. The conclusion is that publicly available information in financial statements, which presumably meets the minimum disclosure requirements, is inadequate to ascertain whether firms are engaging in speculative activities. These findings are important on their own accord given the recent rash of corporate scandals related to the financial reporting of off-balance sheet asset. In addition, this conclusion supports the importance of using survey data, despite its limitations, to examine firms' speculative activities.

\section{A. Financial statement disclosures and the minimum disclosure requirements}

The accounting standard that established minimum disclosure requirements about derivative instruments in 1997 was FASB Statement No. 119, "Disclosure about Derivative Financial Instruments and Fair Value of Financial Instruments." SFAS 119 required that firms "distinguish 
between derivative instruments held or issued for: trading purposes and purposes other than trading." For trading instruments, ${ }^{25}$ firms were required to disclose separately for assets and liabilities the average fair value during the period and the end-of-period fair value. They also were required to disclose net gains and losses during the period by class, such as FX or interest rates. For instruments held for purposes other than trading, firms were required to disclose among other things: "A description of the entities objectives for holding or issuing the derivative financial instruments, the context needed to understand those objectives, and its strategies for achieving those objectives." The standard encouraged firms to exceed these minimum requirements. SEC disclosure rules at the time of the survey (Regulation S-K, Item 305) also required firms to segregate trading and non-trading portfolios, where "trading" has the same meaning as in the accounting standards.

The firms that disclose speculating in the anonymous survey do not report these activities. ${ }^{26}$ Six of the 13 firms state that they do not use derivatives for trading purposes, and three of these six also state explicitly that they do not use derivatives for speculative purposes. Five of the remaining seven firms that admit to speculating in the survey do not discuss trading or speculation in their disclosures. In fact, only one of the 13 firms discloses that it uses derivatives in minor amounts for trading purposes and one other admits that it enters into certain transactions to create exposures. Thus, for the firms where we most expect to see a discussion of the use of derivatives for speculative purposes, the financial statements do not provide investors with information that corresponds with the firm's activities. In most cases, the disclosures contradict the survey responses.

\footnotetext{
${ }^{25}$ GAAP applicable at the time defined trading purposes as: “...including dealing and other trading activities measured at fair value with gains and losses recognized in earnings.” (SFAS No. 119). Thus, derivative instruments that did not qualify for hedge accounting treatment were considered trading securities. It is worth noting that the FASB had to issue clarifying statements for SFAS 119 associated with the definition of "trading."

${ }^{26}$ When we describe footnote wording throughout this section, we do not quote the actual words in order to preserve the anonymity of the respondent. Our description conveys the spirit of the survey respondent's disclosure.
} 
The disclosures about speculation do not appear to reflect the overall quality of a firm's

disclosures. Analyst ratings of disclosure quality are available for six of the 13 frequent speculators. ${ }^{27}$

Three of the six firms are ranked as relatively good disclosers within their industries; the other three

are relatively poor. There is no consistent pattern between these rankings and the nature of the

disclosures about derivatives. ${ }^{28}$ In addition, all of the frequent speculators were audited by one of the

Big-six public accounting firms in 1997 and they all received unqualified opinions.

The deficient disclosures about speculation are not evidence of accounting fraud. Our

definition of speculation is not part of GAAP, and firms may consider actively taking a position based

on a market view to be a "non-trading" activity. ${ }^{29}$ In addition, while our speculators frequently take

positions, GAAP requires disclosure of the positions only if they are material. ${ }^{30}$ Nonetheless, whether

we do not observe disclosure because the accounting rules do not require it or because firms are not

implementing the rules properly, the end result is that the financial statements do not provide an

accurate picture of whether the firm engages in speculation as we have defined it.

The opaqueness of the disclosures by the frequent speculators is somewhat inconsistent with

their survey responses. In response to Question $4 \mathrm{a}$, part $\mathrm{f}, 77 \%$ of the frequent speculators report a

\footnotetext{
${ }^{27}$ The Association for Investment Management and Research (AIMR) provided disclosure quality scores for select firms typically the largest firms - within industry groups through 1996. The AIMR ranked firms in three categories: annual and other required reports, quarterly reports and other published information, and investor relations.

${ }^{28}$ The firm that admits to "trading" is a good discloser, but the firm that admits that it "creates exposures" is poor. Two of the four firms that deny "trading" are good disclosers; two are poor. And, one good discloser and one poor discloser specifically deny "speculating."

${ }^{29}$ The two frequent speculators that responded to the follow-up survey indicated that they classify all derivatives positions that are actively taken based on market views as hedging instruments, consistent with the reporting of such positions in the annual report.

${ }^{30}$ GAAP defines material as follows: "The magnitude of an omission or misstatement of accounting information that, in the light of surrounding circumstances, makes it probable that the judgment of a reasonable person relying on the information would have been changed or influenced by the omission or misstatement." (Statement of Accounting Concepts No. 2, FASB, 1980.) Case law interprets the GAAP definition of materiality. An omitted fact is material if a "reasonable shareholder" is substantially likely to consider it important (TSC Industries, Inc. v. Northway, Inc., 426 U.S. 438, 1976;Basic Inc. v. Levinson 485 U.S. 224, 1988). SEC v. Texas Gulf Sulphur Co., 401 F.2d, at 849 addressed the issue of materiality specifically for contingent or uncertain events such as potential losses from speculation, and concludes that the reasonable shareholder criterion "will depend at any given time upon a balancing of both the indicated probability that the event will occur and the anticipated magnitude of the event in light of the totality of the company activity." The SEC echoes the definition of materiality from GAAP and emphasizes that numerical thresholds and rules of thumb for materiality are inappropriate; the facts and circumstances of the event/transaction, including the total "mix" of available information, should dictate materiality (Staff Accounting Bulletin $\{\mathrm{SAB}\}$ No. 99 - "Materiality").
} 
moderate or high degree of concern about the SEC disclosure requirements with respect to derivatives. This compares to $66 \%$ of the sometimes speculators and $67 \%$ of the firms that never speculate. In Question 4a, part e, 69.2\% of the frequent speculators, express low concern about reactions by analysts or investors with respect to derivatives whereas only $32.7 \%$ of non-speculators express low concern (the difference in means is significant at the $10 \%$ level or better). A high concern about the SEC but a low concern about other financial statement users should suggest that the frequent speculators would be more forthcoming in their financial statements than they are.

\section{B. Financial statement disclosures relative to non-speculators}

In addition to assessing the disclosures of the frequent speculators relative to the minimum requirements, we also compare them to the disclosures made by firms that sometimes and never speculate with derivatives. We examine the financial statements for a random sample of $25 \%$ of the survey respondents that indicated that they sometimes use derivatives to ( 15 firms) and $25 \%$ of the firms that respond that they never use derivatives to actively take positions (26 firms). In summary, the comparison indicates that there is no correspondence between the degree of speculation indicated by the survey responses and the revelation of speculative behavior in the financial statements. The disclosures across the groups are similar.

Only one of the 15 firms that sometimes speculate according to the survey discloses that it uses derivatives for trading purposes. The remaining 14 firms disclose that they use derivatives and mention hedging but do not use words such as "trading purposes", "speculative purposes", or "speculation." Fourteen of the 26 firms (54\%) that never speculate according to the survey explicitly state in their derivatives footnote that they do not use derivatives for trading or speculative purposes. The remaining 12 firms discuss hedging programs but do not use the phrases noted above. The high frequency of denials for this group is consistent with the unraveling models that predict full disclosure 
(Grossman, 1981 and Milgrom, 1981). ${ }^{31}$ If managers believe that investors view speculative activities as unfavorable as characterized in the financial press, then firms that never speculate have incentives to report that they do not. Unfortunately, the statement is not credible given that an even greater percentage of the frequent speculators make similar denials.

\section{Conclusions}

Our analysis characterizes corporate speculators. The main conclusions are that firms take positions based on a view - they speculate - when they believe it to be a profitable activity, not to create upside potential and thereby increase risk without return. While it could be profitable because of transaction cost advantages, evidence also suggests that speculators likely believe they have an information advantage in either FX or IR markets. The firms that speculate have compensation arrangements and bonding mechanisms that encourage (or at least do not discourage) CFOs from speculating. However, firms that frequently speculate put in place internal monitoring mechanisms and controls to manage the potential abuse of the instruments, including more frequent and sophisticated valuations, more frequent reporting to the board, and policies that assure better counterparties.

The survey also provides a unique opportunity to evaluate the informativeness of a firm's financial reporting of its derivatives use. We can compare survey responses, which we view as an accurate representation of the firm's activities, to the data that are publicly reported. Without confidential survey data that reveals the "true" nature of the underlying transactions, it is impossible to evaluate the adequacy of the disclosures. The analysis suggests that investors, using publicly-available data, could not identify the firms speculate.

\footnotetext{
${ }^{31}$ These studies predict full disclosure, even by firms with unfavorable private information. The firm with the "best" private information has incentives to disclose it, but that leaves the firm with the second-best private information to be pooled with the remaining firms. So, the second-best firm also discloses and so on, which results in full disclosure by all firms except the one with the most unfavorable information.
} 
The analysis of both internal controls and general bonding contracts allows us to make a general statement about the role of governance mechanisms to control agency conflicts. In a complete contracting setting, firms choose mechanisms optimally to align incentives of principals and agents $e x$ ante or to create ex post costs of deviating from actions that maximize firm value. With incomplete or costly contracting, however, the second-best contract may induce or at least allow managers to take specific actions that are not value-maximizing for the firm. For example, a firm that provides optimal incentives to use derivatives to hedge without further monitoring and control allows for the possibility that an agent might take excessive risks with these instruments. Internal controls that are directed at specific managerial actions can help complete the contracting process.

An important question is whether our characterizations of speculators generalize to the current time period. One could assert that the costs associated with speculation have risen since the date of the survey because it was taken prior to Enron's bankruptcy and other accounting scandals that refocused investor attention on corporate transparency and governance, especially related to derivatives. It is not clear, however, that the increased negative attention has increased the cost of speculation. The costs increase only if investors know that firms are speculating, and our results suggest that such information is not transparent in the financial statements. While the reporting standards continue to evolve, it is not clear that the financial statements are any more transparent today than they were in 1998 with respect to speculation as we have defined it. In fact, representatives from one of the frequent speculators from 1998 privately suggest that firms probably still speculate, but they "rationalize" this activity differently today (anonymous firm, 2004). 
Table I

\section{Summary Statistics on Derivatives Usage Survey}

Summary statistics for the Wharton/Chase/CIBC Capital Markets Survey of Derivatives Usage by U.S. Non-Financial Firms for 1998.

\begin{tabular}{|c|c|c|}
\hline & $\begin{array}{c}\text { Respondents } \\
(\mathrm{N}=341) \\
\end{array}$ & $\begin{array}{c}\text { Non-Respondents } \\
(\mathrm{N}=\mathbf{1 , 0 4 7}) \\
\end{array}$ \\
\hline \multicolumn{3}{|l|}{ Number that report using derivatives: } \\
\hline FX forwards, futures, swaps, options, or other & 161 & NA \\
\hline Interest rate forwards, futures, swaps, options, or other & 157 & NA \\
\hline \multicolumn{3}{|l|}{ Industry: } \\
\hline Agriculture and forestry & 1 & 7 \\
\hline Mining, oil and gas exploration, and construction & 27 & 50 \\
\hline Food, textiles, lumber, paper, and chemicals & 80 & 233 \\
\hline Rubber, stone, metals, heavy machinery & 110 & 375 \\
\hline Transportation and communications & 55 & 113 \\
\hline $\begin{array}{l}\text { Wholesale durable and non-durable goods, } \\
\text { retail, and restaurants }\end{array}$ & Wholesale durable and non-durable goods, & 147 \\
\hline Financial services & 3 & 4 \\
\hline For-profit services & 18 & 96 \\
\hline Healthcare and social services & 7 & 18 \\
\hline Governmental and quasi-governmental services & - & 4 \\
\hline \multicolumn{3}{|l|}{ Firm characteristics: } \\
\hline \multicolumn{3}{|l|}{ Total assets (\$ millions) } \\
\hline Mean & $6,027.51$ & $2,663.21$ \\
\hline Median & 644.69 & 418.07 \\
\hline Std deviation & $24,197.08$ & $9,157.02$ \\
\hline \multicolumn{3}{|l|}{ Sales (\$ millions) } \\
\hline Mean & $4,765.15$ & $2,682.00$ \\
\hline Median & 721.79 & 486.85 \\
\hline Std deviation & $13,878.24$ & $8,322.81$ \\
\hline \multicolumn{3}{|l|}{ Firm Size (\$ millions) } \\
\hline Mean & $8,522.96$ & $4,240.96$ \\
\hline Median & 872.15 & 568.47 \\
\hline Std deviation & $29,443.80$ & $14,141.36$ \\
\hline
\end{tabular}




\section{Table II \\ Financial Characteristics of Speculators and Non-Speculators}

Panel A presents financial characteristics of survey respondents. The S v. NS column (F v. S) $\{$ F v. NS $\}$ reports the significance level of a t-test comparing the mean values for the sometimes speculators versus the non-speculators (frequent v. sometimes speculators) \{frequent v. non-speculators\}. ${ }^{*}, * * * * *$ denotes significance at the $10 \%, 5 \%$, and $1 \%$ level. Panel B presents multinomial logit regression estimates of the relation between the likelihood that a firm frequently, sometimes or never actively takes positions based on a view about currency or interest rates and financial characteristics. $\Delta$ Prob. measures the marginal change in the probability of being a non-speculator, sometimes speculator, or frequent speculator resulting from a change in the independent variable. The marginal effects of the regressors on the probabilities are calculated at the means of the regressors across all available observations. P-values are for the marginal effect estimates. Variable definitions are in Appendix B.

Panel A: Univariate analysis

\begin{tabular}{|c|c|c|c|c|c|c|c|c|c|}
\hline \multirow[b]{2}{*}{ Variable } & \multicolumn{2}{|c|}{$\begin{array}{c}\text { Non-Speculators } \\
\quad(\mathrm{N}=102)\end{array}$} & \multicolumn{2}{|c|}{$\begin{array}{c}\text { Sometimes } \\
\text { speculators } \\
(\mathrm{N}=61)\end{array}$} & \multirow[t]{2}{*}{$\begin{array}{c}\text { S } \\
\text { v. } \\
\text { NS } \\
\end{array}$} & \multicolumn{2}{|c|}{$\begin{array}{l}\text { Frequent } \\
\text { speculators } \\
(\mathrm{N}=13)\end{array}$} & \multirow[t]{2}{*}{$\begin{array}{l}\mathrm{F} \\
\mathrm{V} . \\
\mathrm{S}\end{array}$} & \multirow[t]{2}{*}{$\begin{array}{c}\text { F } \\
\text { v. } \\
\text { NS } \\
\end{array}$} \\
\hline & Mean & Std. Dev & Mean & Std. Dev & & Mean & Std. Dev & & \\
\hline Firm size: SIZE (log \$MM) & 8.3852 & 1.7057 & 7.5055 & 1.9475 & $* * *$ & 9.0271 & 1.4937 & ** & \\
\hline I-SIZE & 22.8128 & 113.0809 & 8.9292 & 23.6553 & & 14.9925 & 17.0109 & & \\
\hline \multicolumn{10}{|l|}{ Growth/Investment opportunities } \\
\hline Average book-to-market ratio ${ }^{32}$ & 0.4720 & 0.4037 & 0.4495 & 0.4168 & & 0.2948 & 0.0993 & $* *$ & $* * *$ \\
\hline R\&D expenses/sales & 0.0260 & 0.0476 & 0.0224 & 0.0417 & & 0.0537 & 0.0930 & & \\
\hline \multicolumn{10}{|l|}{ Short and long-term liquidity } \\
\hline Quick ratio & 0.3042 & 0.7233 & 0.3218 & 0.5816 & & 0.1843 & 0.1750 & & \\
\hline Interest coverage ratio ${ }^{33}$ & 8.9796 & 24.7384 & 7.0795 & 10.8613 & & 7.3623 & 5.9248 & & \\
\hline Long-term debt ratio & 0.2958 & 0.1871 & 0.2343 & 0.1657 & $* *$ & 0.1656 & 0.0720 & $* *$ & $* * *$ \\
\hline S\&P debt rating & 7.4375 & 3.3747 & 7.9737 & 3.3731 & & 7.0000 & 3.2193 & & \\
\hline
\end{tabular}

Panel B: Multinomial logit analysis

\begin{tabular}{lrrrrrr} 
& \multicolumn{2}{c}{ Non-speculators } & \multicolumn{2}{c}{ Sometimes speculators } & \multicolumn{2}{c}{ Frequent speculators } \\
& $\Delta$ Prob. & P-value & $\Delta$ Prob. & P-value. & $\Delta$ Prob. & P-value \\
\cline { 2 - 7 } Constant & -0.6586 & 0.0076 & 0.7520 & 0.0018 & -0.0935 & 0.2853 \\
LSIZE & 0.0713 & 0.0038 & -0.0817 & 0.0008 & 0.0104 & 0.1890 \\
Book to Market (Ave) & 0.1409 & 0.1978 & -0.1124 & 0.2763 & -0.0285 & 0.6501 \\
Quick Ratio (Ave) & 0.0833 & 0.2151 & -0.0320 & 0.6071 & -0.0513 & 0.2607 \\
Debt/Equity (Ave) & 0.6659 & 0.0068 & -0.4660 & 0.0511 & -0.1999 & 0.0434 \\
Number of Obs. (168) & \multicolumn{2}{c}{98} & & & & \\
\end{tabular}

\footnotetext{
${ }^{32}$ Excludes a non-speculator with an average $\mathrm{BM}=-0.001$.

${ }^{33}$ Excludes a sometimes speculator with an interest coverage ratio $>1000$. The next highest interest coverage ratio for the sometimes speculators is approximately 50 .
} 


\section{Table III \\ Activities of Speculators and Non-Speculators}

Descriptive statistics of risk-related activities for firms that never, sometimes, and frequently actively take positions based on a view about FX or interest rates. The S v. NS column (F v. S) $\{\mathrm{F} \mathrm{v}$. NS $\}$ reports the significance level of a $\mathrm{t}$-test comparing the mean values for the sometimes speculators versus the non-speculators (frequent $\mathrm{v}$. sometimes speculators) \{frequent $\mathrm{v}$. non-speculators\}. $*, * *, * * *$ denotes significance at the $10 \%, 5 \%$, and $1 \%$ level.

\begin{tabular}{|c|c|c|c|c|c|c|}
\hline & $\begin{array}{c}\text { Non- } \\
\text { Speculators }\end{array}$ & $\begin{array}{l}\text { Sometimes } \\
\text { speculators }\end{array}$ & $\begin{array}{c}\mathrm{S} \\
\mathrm{V} . \\
\mathrm{NS}\end{array}$ & $\begin{array}{c}\text { Frequent } \\
\text { speculators }\end{array}$ & $\begin{array}{l}\mathrm{F} \\
\mathrm{v} . \\
\mathrm{S}\end{array}$ & $\begin{array}{c}\text { F } \\
\text { v. } \\
\text { NS }\end{array}$ \\
\hline Panel A: Based on frequency of $F X$ derivatives use & $n=91$ & $n=35$ & & $n=9$ & & \\
\hline$\%$ of operating revenues in foreign currency & $21.74 \%$ & $18.71 \%$ & & $37.78 \%$ & $* * *$ & $* * *$ \\
\hline$\%$ of operating costs in foreign currency & 18.59 & 15.43 & & 34.44 & $* * *$ & $* * *$ \\
\hline Hedge foreign repatriations & 0.9011 & 0.8571 & & 1.6250 & $* * *$ & $* * *$ \\
\hline \multicolumn{7}{|l|}{ Hedge contractual commitments } \\
\hline i. on-balance sheet transactions & 1.4607 & 1.1714 & ** & 1.5556 & & \\
\hline ii. off-balance sheet transactions & 0.8506 & 0.7143 & & 0.7500 & & \\
\hline Hedge anticipated transactions one year or less & 1.1889 & 1.4706 & $* *$ & 1.5556 & & \\
\hline Hedge anticipated transactions over one year & 0.5843 & 0.8857 & ** & 0.6667 & & \\
\hline Hedge economic/competitive exposure & 0.4432 & 0.5429 & & 0.4444 & & \\
\hline Hedge translation of foreign accounting statements & 0.4713 & 0.3429 & & 1.1111 & $* * *$ & ** \\
\hline Arbitrage borrowing rates across currencies & 0.3678 & 0.4000 & & 0.7778 & & $* *$ \\
\hline Panel B: Based on frequency of IR derivatives use & $n=81$ & $n=49$ & & $n=6$ & & \\
\hline$\%$ of operating revenues in foreign currency & $16.14 \%$ & $17.60 \%$ & & $24.17 \%$ & & \\
\hline$\%$ of operating costs in foreign currency & 13.98 & 14.20 & & $21.67 \%$ & & \\
\hline Swap from fixed rate to floating rate debt & 0.6282 & 0.7272 & & 1.0000 & & \\
\hline Swap from floating rate to fixed rate debt & 0.8642 & 1.0204 & $*$ & 1.5000 & $* *$ & $* * *$ \\
\hline Fix in advance the rate (spread) on new debt & 0.5065 & 0.6739 & & 1.2000 & * & $* * *$ \\
\hline Reduce costs/lock-in rates based on market view & 0.3896 & 0.7778 & $* * *$ & 1.6000 & & $* *$ \\
\hline Panel C: Based on frequency of FX or IR use & $n=93$ & $n=55$ & & $n=12$ & & \\
\hline Return volatility & 0.0211 & 0.0235 & & 0.0173 & $* * *$ & $* *$ \\
\hline Number of segments & 2.5143 & 2.0256 & & 2.1111 & & \\
\hline Segment concentration ratio & 0.7805 & 0.8371 & & 0.7771 & & \\
\hline
\end{tabular}




\section{Table IV \\ Equity-based compensation of Speculators and Non-Speculators}

Panel A reports univariate comparisons of equity-based compensation variables across the survey respondents that never, sometimes, and frequently actively take positions based on a view about currency or interest rates. The $\mathrm{S} v$. NS column (F v. S) $\{\mathrm{F} \mathrm{v}$. NS $\}$ reports the significance level of a t-test comparing the mean values for the sometimes speculators versus the non-speculators (frequent $\mathrm{v}$. sometimes speculators) \{frequent $\mathrm{v}$. non-speculators $\} .{ }^{*}, * *, * * *$ denotes significance at the $10 \%, 5 \%$, and $1 \%$ level. Panel B reports multinomial logit regression estimates of the relation between the likelihood that a firm frequently, sometimes or never actively takes positions based on a view about FX or interest rates and the equity-based compensation variables. $\Delta$ Prob. measures the marginal change in the probability of being a non-speculator, sometimes speculator, or frequent speculator resulting from a change in the independent variable, calculated at the means of the regressors across all available observations. P-values are for the marginal effect estimates. Variable definitions are in Appendix B.

\begin{tabular}{|c|c|c|c|c|c|c|c|c|c|}
\hline \multicolumn{10}{|c|}{ Panel A: Univariate analysis } \\
\hline & \multirow{3}{*}{\multicolumn{2}{|c|}{$\begin{array}{l}\text { Non-Speculators } \\
\qquad(\mathrm{N}=102)\end{array}$}} & \multirow{3}{*}{\multicolumn{2}{|c|}{$\begin{array}{c}\text { Sometimes } \\
\text { speculators } \\
(\mathrm{N}=61)\end{array}$}} & $\mathrm{S}$ & \multirow{3}{*}{\multicolumn{2}{|c|}{$\begin{array}{c}\text { Frequent } \\
\text { speculators } \\
(\mathrm{N}=13)\end{array}$}} & $\mathrm{F}$ & $\mathrm{F}$ \\
\hline & & & & & $\mathrm{v}$. & & & $\mathrm{v}$. & $\mathrm{v}$. \\
\hline & & & & & NS & & & $\mathrm{S}$ & NS \\
\hline & Mean & Std. Dev & Mean & Std. Dev & & Mean & Std. Dev & & \\
\hline \multicolumn{10}{|l|}{ Compensation variables: } \\
\hline CEO wealth DELTA & 718.38 & 1486.71 & 457.85 & 610.92 & & 601.91 & 502.85 & & \\
\hline CEO wealth VEGA & 90.47 & 82.72 & 91.19 & 100.29 & & 123.42 & 130.46 & & \\
\hline CFO wealth DELTA & 78.89 & 101.68 & 102.63 & 114.79 & & 165.09 & 144.15 & & $*$ \\
\hline CFO wealth VEGA & 20.48 & 18.27 & 25.78 & 23.43 & & 31.29 & 25.58 & & \\
\hline \multicolumn{10}{|c|}{ Panel B: Multinomial logit analysis } \\
\hline & \multicolumn{2}{|c|}{ Non-speculators } & \multicolumn{3}{|c|}{ Sometimes speculators } & \multicolumn{4}{|c|}{ Frequent speculators } \\
\hline & $\Delta$ Prob. & P-value & \multicolumn{2}{|c|}{$\Delta$ Prob. } & P-value. & \multicolumn{2}{|c|}{$\Delta$ Prob. } & \multicolumn{2}{|c|}{ P-value } \\
\hline Constant & -0.7662 & 0.0740 & \multicolumn{2}{|c|}{0.9151} & 0.025 & \multicolumn{2}{|c|}{-0.1489} & \multicolumn{2}{|c|}{0.392} \\
\hline Log(Size) & 0.1162 & 0.0433 & \multicolumn{2}{|c|}{-0.1256} & 0.023 & \multicolumn{2}{|c|}{0.0093} & \multicolumn{2}{|c|}{0.659} \\
\hline Debt/Equity (AVE) & 0.8346 & 0.0510 & \multicolumn{2}{|c|}{-0.5063} & 0.217 & \multicolumn{2}{|c|}{-0.3283} & \multicolumn{2}{|c|}{0.162} \\
\hline CEO Wealth Delta & 0.0002 & 0.0789 & \multicolumn{2}{|c|}{-0.0001} & 0.487 & \multicolumn{2}{|c|}{-0.0001} & \multicolumn{2}{|c|}{0.058} \\
\hline CEO Wealth Vega & -0.0031 & 0.0589 & \multicolumn{2}{|c|}{0.0024} & 0.106 & \multicolumn{2}{|c|}{0.0007} & \multicolumn{2}{|c|}{0.229} \\
\hline CFO Wealth Delta & -0.0022 & 0.0977 & \multicolumn{2}{|c|}{0.0014} & 0.244 & \multicolumn{2}{|c|}{0.0009} & \multicolumn{2}{|c|}{0.072} \\
\hline CFO Wealth Vega & 0.0036 & 0.5291 & \multirow[t]{2}{*}{-0.0021} & & 0.693 & \multicolumn{2}{|c|}{-0.0015} & \multicolumn{2}{|c|}{0.523} \\
\hline Number of Obs. (83) & \multicolumn{2}{|c|}{434} & & 28 & & & 11 & & \\
\hline
\end{tabular}




\section{Table V \\ Compensation of Speculators and Non-Speculators}

Univariate comparisons of compensation-related variables across the survey respondents that never, sometimes, and frequently actively take positions based on a view about currency or interest rates. The $\mathrm{S}$ v. NS column $(\mathrm{F} v$. S) $\{\mathrm{F}$ v. NS \} reports the significance level of a t-test comparing the mean values for the sometimes speculators versus the nonspeculators (frequent v. sometimes speculators) \{frequent v. non-speculators\}. Variable definitions are in Appendix B. *, $* *, * * *$ denotes significance at the $10 \%, 5 \%$, and $1 \%$ level.

\begin{tabular}{|c|c|c|c|c|c|c|c|}
\hline & & $\begin{array}{c}\text { Non- } \\
\text { Speculators } \\
(\mathrm{n}=102)\end{array}$ & $\begin{array}{c}\text { Sometimes } \\
\text { speculators } \\
\quad(\mathrm{n}=61)\end{array}$ & $\begin{array}{c}\text { S } \\
\text { v. } \\
\text { NS }\end{array}$ & $\begin{array}{l}\text { Frequent } \\
\text { speculators } \\
(\mathrm{n}=13)\end{array}$ & $\begin{array}{l}\mathrm{F} \\
\mathrm{v} . \\
\mathrm{S}\end{array}$ & $\begin{array}{c}\text { F } \\
\text { v. } \\
\text { NS }\end{array}$ \\
\hline \multirow[t]{2}{*}{ CEO: } & Bonus in thousands of dollars & $\$ 945.72$ & 573.55 & $* *$ & $\$ 830.04$ & & \\
\hline & Bonus as a $\%$ of cash compensation & 0.423 & 0.395 & & 0.491 & $* *$ & * \\
\hline \multirow[t]{2}{*}{ CFO: } & Bonus in thousands of dollars & $\$ 260.61$ & 175.46 & $*$ & $\$ 390.29$ & * & \\
\hline & Bonus as a $\%$ of cash compensation & 0.367 & 0.313 & * & 0.442 & $* *$ & \\
\hline \multicolumn{8}{|c|}{$\%$ that evaluate the risk management function by: } \\
\hline \multicolumn{2}{|c|}{ Reduced volatility relative to a benchmark } & $45.7 \%$ & $40.4 \%$ & & $8.3 \%$ & $* * *$ & $* * *$ \\
\hline \multicolumn{2}{|r|}{ Increased profit relative to a benchmark } & 16.3 & 24.6 & & 66.7 & $* * *$ & $* * *$ \\
\hline \multicolumn{2}{|r|}{ Absolute profit/loss } & 14.1 & 19.3 & & 16.7 & & \\
\hline \multicolumn{2}{|c|}{ Risk adjusted performance } & 23.9 & 15.8 & & 8.3 & & \\
\hline \multicolumn{2}{|c|}{ Benchmark for debt portfolio: ${ }^{34}$} & $n=83$ & $n=50$ & & $n=6$ & & \\
\hline \multicolumn{2}{|c|}{ None } & $38.3 \%$ & $38.8 \%$ & & $50.0 \%$ & & \\
\hline \multicolumn{2}{|c|}{ Volatility of interest expense } & 16.0 & 10.2 & & - & $* *$ & $* * *$ \\
\hline \multicolumn{2}{|c|}{ Cost of funds v. market index } & 25.9 & 28.6 & & 16.7 & & \\
\hline \multicolumn{2}{|r|}{ Cost of funds v. duration-matched portfolio } & 6.2 & 12.2 & & 33.3 & & \\
\hline \multicolumn{2}{|c|}{ Cost of funds v. portfolio with specified ratio } & 22.2 & 26.5 & & 33.3 & & \\
\hline \multicolumn{2}{|c|}{ Other } & 8.6 & 4.1 & & 16.7 & & \\
\hline \multicolumn{2}{|c|}{ Benchmark for FX activities: } & $n=92$ & $n=35$ & & $n=9$ & & \\
\hline \multicolumn{2}{|c|}{ None } & $34.8 \%$ & $21.9 \%$ & & - & $* * *$ & $* * *$ \\
\hline \multicolumn{2}{|c|}{ Forward rates at beg. of period } & 23.6 & 40.6 & $*$ & $44.4 \%$ & & \\
\hline \multicolumn{2}{|c|}{ Spot rates at beg. of period } & 18.0 & 15.6 & & 22.2 & & \\
\hline \multicolumn{2}{|c|}{ Baseline $\%$ hedged strategy } & 10.1 & 15.6 & & 22.2 & & \\
\hline \multicolumn{2}{|c|}{ Other } & 13.5 & 6.3 & & 11.1 & & \\
\hline \multirow{2}{*}{\multicolumn{2}{|c|}{ Hubris: LONGHOLDER }} & $n=31$ & $n=12$ & & $n=4$ & & \\
\hline & & 0.065 & 0.167 & & 0.250 & & \\
\hline
\end{tabular}

\footnotetext{
${ }^{34}$ More than one can apply.
} 


\section{Table VI \\ Governance of Speculators and Non-Speculators}

Panel A reports univariate comparisons of governance indices across the survey respondents that never, sometimes, and frequently actively take positions based on a view about currency or interest rates. The S v. NS column (F v. S) $\{\mathrm{F} \mathrm{v}$. NS \} reports the significance level of a t-test comparing the mean values for the sometimes speculators versus the nonspeculators (frequent $\mathrm{v}$. sometimes speculators) \{frequent $\mathrm{v}$. non-speculators\}. ${ }^{*}, * *, * * *$ denotes significance at the $10 \%$, $5 \%$, and $1 \%$ level. Panel B reports multinomial logit regression estimates of the relation between the likelihood that a firm frequently, sometimes or never actively takes positions based on a view about FX or interest rates and the governance indices. $\Delta$ Prob. measures the marginal change in the probability of being a non-speculator, sometimes speculator, or frequent speculator resulting from a change in the independent variable, calculated at the means of the regressors across all available observations. P-values are for the marginal effect estimates. Variable definitions are in Appendix B.

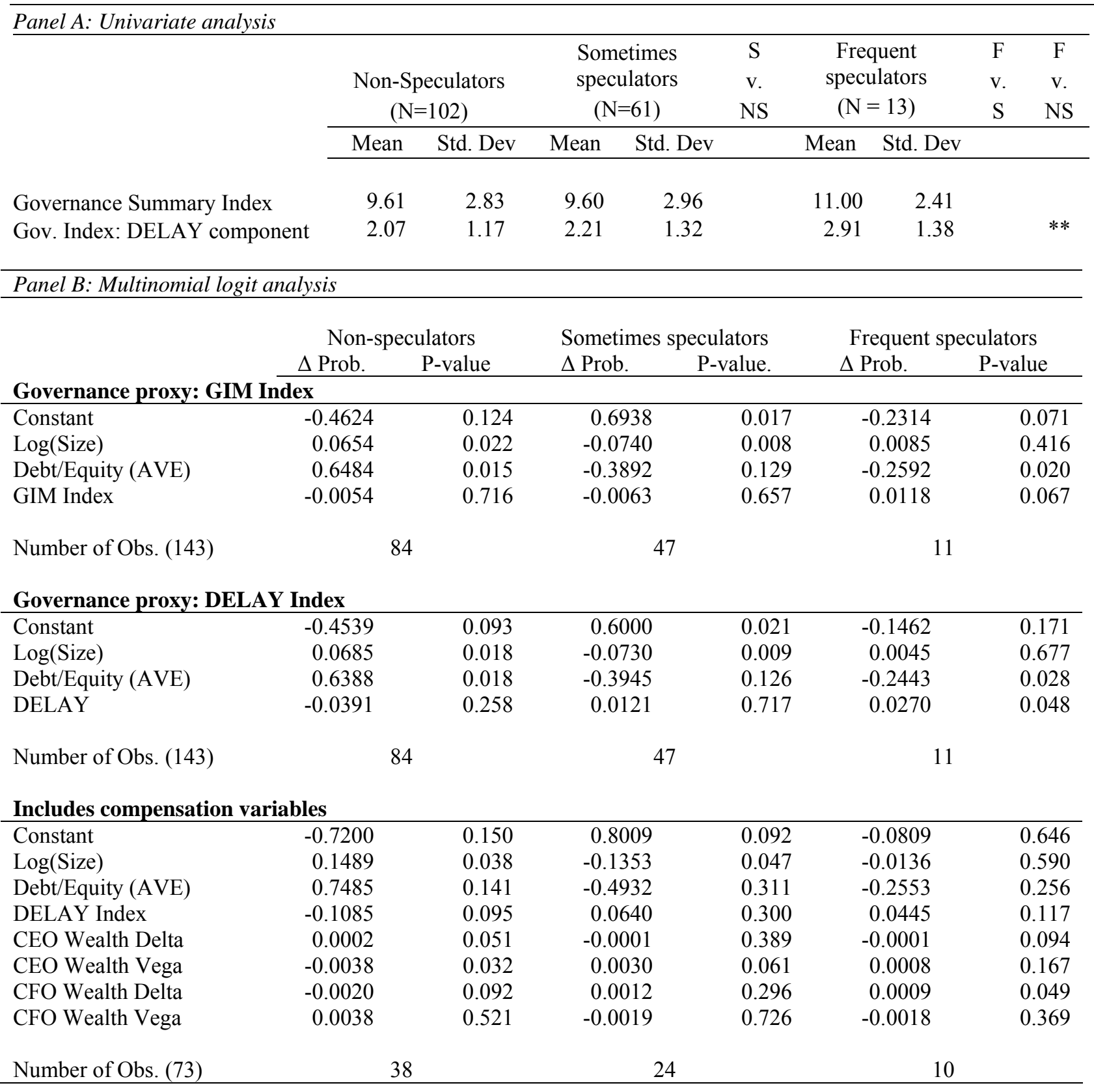




\section{Table VII \\ Internal Controls of Firms that Frequently, Sometimes, or Never Speculate}

Descriptive statistics of the internal controls for firms that never, sometimes, and frequently actively take positions based on a view about FX or interest rates. The $\mathrm{S} v$. NS column $(\mathrm{F} \mathrm{v} . \mathrm{S})\{\mathrm{F} \mathrm{v}$. NS $\}$ reports the significance level of a t-test comparing the mean values for the sometimes speculators versus the non-speculators (frequent $\mathrm{v}$. sometimes speculators) \{frequent $\mathrm{v}$. non-speculators\}. $* * *, * * *$ denotes significance at the $10 \%, 5 \%$, and $1 \%$ level.

\begin{tabular}{|c|c|c|c|c|c|c|c|}
\hline \multicolumn{2}{|c|}{ Survey question } & \multicolumn{6}{|c|}{ Frequency of taking a view } \\
\hline \# & Question & $\begin{array}{c}\text { Never } \\
(\mathrm{n}=102)\end{array}$ & $\begin{array}{l}\text { Sometimes } \\
\quad(\mathrm{n}=61)\end{array}$ & $\begin{array}{l}\text { S. v } \\
\text { N. }\end{array}$ & $\begin{array}{l}\text { Frequently } \\
\quad(\mathrm{n}=13)\end{array}$ & $\begin{array}{l}\text { F v. } \\
\text { S. }\end{array}$ & $\begin{array}{c}\text { F. v. } \\
\text { N. }\end{array}$ \\
\hline \multirow[t]{4}{*}{3} & Risk management activities are: ${ }^{35}$ & & & & & & \\
\hline & Primarily centralized & $89.2 \%$ & $95.0 \%$ & & $100.0 \%$ & * & $* * *$ \\
\hline & Primarily decentralized; central coordination & 9.8 & 10.0 & & 7.7 & & \\
\hline & Primarily decentralized & 2.9 & - & * & - & & * \\
\hline $17 \mathrm{a}$ & $\%$ with a documented policy & $83.8 \%$ & $74.6 \%$ & & $84.7 \%$ & & \\
\hline \multirow[t]{6}{*}{$17 \mathrm{~b}$} & Frequency of reporting to the BOD: & & & & & & \\
\hline & Monthly & $4.0 \%$ & $1.7 \%$ & & $7.7 \%$ & & \\
\hline & Quarterly & 21.2 & 16.9 & & 38.4 & * & \\
\hline & Annually & 22.2 & 13.6 & & 23.1 & & \\
\hline & As needed/no set schedule & 44.5 & 62.7 & $* *$ & 23.1 & $* * *$ & \\
\hline & Other & 8.1 & 5.1 & & 7.7 & & \\
\hline \multirow[t]{15}{*}{18} & Lowest counterparty rating & & & & & & \\
\hline & Maturities 12 months or less: & & & & & & \\
\hline & AAA & $3.2 \%$ & $10.7 \%$ & * & $7.7 \%$ & & \\
\hline & AA & 20.0 & 19.6 & & 15.4 & & \\
\hline & A & 49.5 & 51.8 & & 76.9 & * & * \\
\hline & BBB & 10.5 & 3.6 & * & - & & $* * *$ \\
\hline & Less than BBB & 4.2 & - & $* *$ & - & & $* *$ \\
\hline & No set policy/Don't know & 12.6 & 14.3 & & - & $* * *$ & $* * *$ \\
\hline & Maturities more than 12 months: & & & & & & \\
\hline & AAA & 5.6 & 11.3 & & 7.70 & & \\
\hline & $\mathrm{AA}$ & 36.7 & 30.2 & & 46.15 & & \\
\hline & A & 35.5 & 45.3 & & 46.15 & & \\
\hline & BBB & 6.7 & 1.9 & & - & & ** \\
\hline & Less than BBB & 2.2 & - & & - & & \\
\hline & No set policy/Don't know & 13.3 & 11.3 & & - & $* *$ & $* * *$ \\
\hline \multirow[t]{7}{*}{19} & Frequency of derivatives portfolio valuation & & & & & & \\
\hline & Daily & $19.2 \%$ & $8.5 \%$ & * & $30.7 \%$ & & \\
\hline & Weekly & 11.1 & 6.8 & & 7.7 & & \\
\hline & Monthly & 27.3 & 30.5 & & 23.1 & & \\
\hline & Quarterly & 22.2 & 27.1 & & 23.1 & & \\
\hline & Annually & 2.0 & 11.9 & $* *$ & - & $* * *$ & \\
\hline & As needed/no set schedule & 18.2 & 15.2 & & 15.4 & & \\
\hline \multirow[t]{4}{*}{20} & Who values the portfolio (ranked $1,2,3$ ) & & & & & & \\
\hline & Dealer that originated the transaction & 1.85 & 1.64 & & 1.90 & & \\
\hline & Other dealer, consultant, or price vendor & 1.96 & 2.16 & & 1.67 & * & \\
\hline & Internal source & 1.58 & 1.94 & $* *$ & 1.42 & $*$ & \\
\hline 6 & Calculates "value at risk" for derivs. portfolio & $41.20 \%$ & $38.33 \%$ & & $69.23 \%$ & $* *$ & * \\
\hline
\end{tabular}

${ }^{35}$ The percentages sum to more than $100 \%$ because firms can manage FX and IR operations differently. 


\section{References}

Adam, Tim, Sudipto Dasgupta, and Sheridan Titman, 2004, Financial constraints, competition and hedging in industry equilibrium, Working paper, Hong Kong University of Science \& Technology, and University of Texas, Department of Finance.

Adam, Tim R. and Chitru S. Fernando, 2005, Are there speculative components in corporate hedging and do they add value? Journal of Financial Economics, forthcoming.

Agrawal, Anup and Gershon N. Mandelker, 1987, Managerial incentives and corporate investment and financing decisions, Journal of Finance 42 (4): 823-837.

Allayannis, Yiorgos and James P. Weston, 2001, The Use of Currency Derivatives and Firm Market Value, The Review of Financial Studies 14 (1): 243-276.

Anonymous firm, telephone interview by the authors, November 2004.

Armstrong, J. Scott and Terry S. Overton, 1977, Estimating nonresponse bias in mail surveys, Journal of Marketing Research 14: 396-402.

Bodnar, Gordon M., Gregory S. Hayt, and Richard C. Marston, 1999, 1998 Wharton Survey on Financial Risk Management by U.S. Non-Financial Firms. In Corporate Risk Management, edited by Gregory W. Brown and Donald H. Chew, 1999, Risk Books, London.

Brown, Gregory W., Peter R. Crabb, and David Haushalter, 2003, Are firms successful at "selective" hedging? Working paper, University of North Carolina.

Brown, Gregory W. and Zeigham Khokher, 2001, Corporate risk, market imperfections, and speculative motives, Working paper, The University of North Carolina.

Campbell, T. and W. A. Kracaw, 1999, Optimal speculation in the presence of costly external financing. In Corporate Risk: Strategies and Management, G. Brown and D. Chew, editors, Risk Publications, London.

Carpenter, Jennifer, 2000, Does option compensation increase managerial risk appetite?, Journal of Finance 55 (5): 2311-2331.

Coates, J. C., 2000, Explaining variation in takeover defenses: Failure in the corporate law market, Harvard Law and Economics Discussion Paper No. 297.

Coles, J., N. Daniel, and L. Naveen, 2004, Managerial incentives and risk taking, Journal of Financial Economics, forthcoming.

Core, J. and W. Guay, 1999, The use of equity grants to manage optimal equity incentive levels, Journal of Accounting and Economics 28 (2), 151-184.

Daines, R. and M. Klausner, 2001, Do IPO charters maximize firm value? Antitakeover protection in IPOs, Journal of Law, Economics, and Organization (17): 83-120. 
DeFusco, R., R. Johnson, and T. Zorn, 1990, The effect of executive stock option plans on stockholders and bondholders, Journal of Finance 45 (2): 617-627.

Diamond, Douglas W, 1984, Financial intermediation and delegated monitoring, Review of Economic Studies 51 (3): 393-414.

Diamond, Douglas, 1991, Monitoring and reputation: The choice between bank loans and directly placed debt, Journal of Political Economy 99: 689-721.

Fahlenbrack, R., 2004, Founder-CEOs and stock market performance, Working paper, The Wharton School.

Financial Accounting Standards Board, 1994, Statement of Financial Accounting Standards No. 119: Disclosure about derivative financial instruments and fair value of financial instruments (FASB, Stamford, CT).

Financial Accounting Standards Board, 1980, Statement of Financial Accounting Concepts No. 2 , Qualitative Characteristics of Accounting Information (FASB, New York).

Géczy, Christopher, Bernadette A. Minton, and Catherine M. Schrand, 1997, Why firms use currency derivatives, Journal of Finance 52, 1323-1354.

Géczy, Christopher, Bernadette A. Minton, and Catherine M. Schrand, 1999, Firms' Use of Currency Derivatives, In Corporate Risk Management, Gregory Brown and Donald Chew, editors, Risk Publications, London.

Gompers, Paul A., Joy L. Ishii, and Andrew Metrick, 2003, Corporate governance and equity prices, The Quarterly Journal of Economics 118 (1): 107-155.

Graham, J.R. and C.R. Harvey, 2001, The theory and practice of corporate finance: Evidence from the field, Journal of Financial Economics 60, 187-243.

Greene, William H., Econometric Analysis, Macmillan Publishing Company, New York, 1993.

Grossman, Sanford J., 1981, The informational role of warranties and private disclosure about product quality, Journal of Law and Economics 24: 461-483.

Guay, Wayne and S. P. Kothari, 2003, How much do firms hedge with derivatives?, Journal of Financial Economics 70 (3): 423-461.

Harris, Milton and Artur Raviv, 1979, Optimal incentive contracts with imperfect information, Journal of Economic Theory 20 (2): 231-259.

Heaton, J. B., 2002, Managerial optimism and corporate finance, Financial Management (Summer): $33-45$.

Hentschel, Ludger and S.P. Kothari, 2001, Are corporations reducing or taking risks with derivatives? Journal of Financial and Quantitative Analysis 36 (1): 93-118.

John, Kose and Simi Kedia, 2002, Design of corporate governance: Role of ownership structure, 
takeovers and bank debt, NYU mimeo.

Jorion, Philippe, 1995, Big Bets Gone Bad, Academic Press, Inc., San Diego, CA.

Kaplan, Steven N. and Luigi Zingales, 1997, Do financing constraints explain why investment is correlated with cash f low?, Quarterly Journal of Economics 112, 169-215.

Lamont, Owen, Christopher Polk, and Jesús Saá-Requejo, 2001, Financial constraints and stock returns, The Review of Financial Studies 14 (2): 529-554.

Merton, R., 1973, Theory of rational option pricing, Bell Journal of Economics and Management Sciences 4, 141-183.

Milgrom, Paul R., 1981, Good news and bad news: Representation theorems and applications, Bell Journal of Economics 2, 380-391.

Murphy, Kevin J., 1999, Executive compensation, in Orley Ashenfelter and David Card, eds., Handbook of Labor Economics, Vol. III, North Holland.

Nance, Deana R., Clifford W. Smith, Jr., and Charles W. Smithson, 1993, On the determinants of corporate hedging, Journal of Finance 48 (1), 267-284.

Rajgopal, Shivaram and Terry Shevlin, 2002, Empirical evidence on the relation between stock option compensation and risk taking, Journal of Accounting and Economics 33 (2): 145-171.

Ross, Stephen A., 2004, Compensation, incentives, and the duality of risk aversion and riskiness, Journal of Finance 59 (1): 207 - 225.

Schrand, Catherine M. and Haluk Unal, 1998, Hedging and coordinated risk management: Evidence from thrift conversions, Journal of Finance 53 (3), 979-1013.

Smith, C. and Rene Stulz, 1985, The determinants of firms' hedging policies, Journal of Financial and Quantitative Analysis 28, 391-405.

Stulz, R., 1996, Rethinking risk management, Journal of Applied Corporate Finance 9, 8-24.

Stulz, R., 2003. Risk Management \& Derivatives, Southwestern College Publishing.

Tate, Geoffrey and Ulrike Malmendier, 2004, CEO overconfidence and corporate investment, Journal of Finance, 60 (6), 2661-2700.

Trahan, E.A., and L.J. Gitman, 1995, Bridging the theory-practice gap in corporate finance: a survey of chief financial officers, Quarterly Review of Economics and Finance 35, 73-87.

Tufano, P., 1996, Who manages risk? An empirical examination of risk management practices in the gold mining industry, Journal of Finance 51, 1097-1137.

Yermack, D., 1995, Do corporations award CEO stock options effectively?, Journal of Financial Economics 39, 237-269. 


\section{Appendix A: Survey Questionnaire \\ Wharton Survey of Financial Risk Management by U.S. Non-Financial Firms \\ 1. Use of Derivatives}

1a. Does your firm use derivatives (forwards, futures, options, swaps)?

(Please circle the appropriate response.)
a. Yes
b. No

Please complete this section if you answered NO to question 1 .

1b. Please indicate the three most important factors in your decision not to use derivatives. (Please rank: 1- Most important; 2 - Second most important; 3 - Third most important.)

a. Insufficient exposure to financial or commodity prices

b. Exposures are more effectively manages by other means

c. Difficulty pricing and valuing derivatives

d. Disclosure requirements of the SEC or the FASB

e. Accounting treatment

f. Concerns about perceptions of derivative use by investors, regulators and the public

g. Costs of establishing and maintaining a derivatives program exceed the expected benefits

h. Other

1c. What percentage of your consolidated operating revenues are in foreign currency? (Please circle the response that is closest.)
a. $0 \%$
b. $5 \%$
c. $10 \%$
d. $15 \%$
e. $20 \%$
f. $25 \%$
g. $30 \%$
h. $40 \%$
i. $50+\%$

1d. What percentage of your consolidated operating costs are in foreign currency? (Please circle the response that is closest.)
a. $0 \%$
b. $5 \%$
c. $10 \%$
d. $15 \%$
e. $20 \%$
f. $25 \%$
g. $30 \%$
h. $40 \%$
i. $50+\%$

Thank you. Please return your survey in the postage paid envelope. 
2. Based upon the notional value of contracts, how does your firm's derivative usage compare to last year? (Please circle the appropriate response.)
a. Usage has increased
b. Usage has decreased
c. Usage has remained constant

3. Which of the following statements best describes your organization's approach to the use of derivatives to manage each of the following forms of risk? (Please indicate with a check in each column.)

\begin{tabular}{|l|l|l|l|l|}
\hline & $\begin{array}{c}\text { Foreign } \\
\text { Exchange }\end{array}$ & $\begin{array}{c}\text { Interest } \\
\text { Rate }\end{array}$ & Commodity & Equity \\
\hline Exposure not managed with derivatives & & & & \\
\hline Risk management activities primarily centralized & & & & \\
\hline $\begin{array}{l}\text { Risk management decisions primarily decentralized } \\
\text { with centralized coordination }\end{array}$ & & & & \\
\hline Risk management activities primarily decentralized & & & & \\
\hline
\end{tabular}

4a. Indicate your degree of concern about the following issues with respect to derivatives. (Please indicate your degree of concern with each issue by checking the appropriate box in each column.)

\begin{tabular}{|l|l|l|l|l|}
\hline & No Concern & Low & Moderate & High \\
\hline a. Accounting treatment & & & & \\
\hline b. Credit Risk & & & & \\
\hline c. Market Risk & & & & \\
\hline d. Monitoring and evaluating hedge results & & & & \\
\hline e. Reaction by analysts or investors & & & & \\
\hline f. SEC disclosure requirements & & & & \\
\hline g. Secondary market liquidity & & & & \\
\hline
\end{tabular}

4b. Indicate the three issues of greatest concern from the list in question $4 \mathrm{a}$. (Please enter the letter from Question 4a for your three most serious concerns.)

\begin{tabular}{|l|c|c|c|c|c|c|c|c|}
\hline & $\mathrm{a}$ & $\mathrm{b}$ & $\mathrm{c}$ & $\mathrm{d}$ & $\mathrm{e}$ & $\mathrm{F}$ & $\mathrm{g}$ & $\mathrm{h}$ \\
\hline Most serious & & & & & & & & \\
\hline Second most serious & & & & & & & & \\
\hline Third most serious & & & & & & & & \\
\hline
\end{tabular}

5. What will be the most likely impact on your firm of the FASB's new rules on derivatives accounting? (Please circle all that apply.)
a. No effect on derivatives use or risk management strategy
b. A reduction in the use of derivatives
c. An increase in the use of derivatives
d. A change in the types of instruments used
e. Alter the timing of hedging transactions
f. A significant change in the firm's overall strategy or approach to risk management

6. Does your firm calculate "value-at-risk" for some or all of its derivatives portfolio?
a. Yes
b. No 


\section{Currency Exposure}

7a. What percentage of your consolidated operating revenues are in foreign currency? (Please circle the response that is closest.)
a. $0 \%$
b. $5 \%$
c. $10 \%$
d. $15 \%$
e. $20 \%$
f. $25 \%$
g. $30 \%$
h. $40 \%$
i. $50+\%$

$7 \mathrm{~b}$. What percentage of your consolidated operating costs are in foreign currency? (Please circle the response that is closest.)

8. Which benchmark does your firm use for evaluating foreign currency risk management over the budget/planning period? (Please circle the response that is appropriate.)
a. Our firm does not use a benchmark
b. Forward rates available at the beginning of the period
c. Spot rates available at the beginning of the period
d. Baseline percent hedged strategy (i.e. X\% hedged)
e. Other benchmark

\section{If your firm does not use currency derivatives, please skip ahead to Section III.}

9. How often does your firm transact in the currency derivatives markets to...

(Please circle the appropriate response for each exposure.)

\begin{tabular}{|c|c|c|c|c|}
\hline $\begin{array}{l}\text { Hedge foreign repatriations } \\
\text { (dividends, royalties, investment } \\
\text { payments) }\end{array}$ & $\begin{array}{c}\text { Not } \\
\text { Applicable }\end{array}$ & Never & Sometimes & Frequently \\
\hline Hedge contractual commitments & & & \\
\hline $\begin{array}{r}\text { i. on-balance sheet transactions } \\
\text { (accounts receivable/payable) }\end{array}$ & & & & \\
\hline $\begin{array}{r}\text { ii. off-balance sheet transactions } \\
\text { (unfilled or pending } \\
\text { contracts) }\end{array}$ & & & & \\
\hline $\begin{array}{l}\text { Hedge anticipated transactions one } \\
\text { year or less }\end{array}$ & & & & \\
\hline $\begin{array}{l}\text { Hedge anticipated transactions over } \\
\text { one year }\end{array}$ & & & & \\
\hline $\begin{array}{l}\text { Hedge economic/competitive } \\
\text { exposure }\end{array}$ & & & & \\
\hline $\begin{array}{l}\text { Hedge translation of foreign } \\
\text { accounting statements }\end{array}$ & & & & \\
\hline $\begin{array}{l}\text { Arbitrage borrowing rates across } \\
\text { currencies(currency swaps in } \\
\text { association with foreign currency } \\
\text { borrowings) }\end{array}$ & & & & \\
\hline
\end{tabular}


10. What percentage of the following categories of exposures do you typically hedge?

(Please indicate the appropriate percentage under each exposure category.)

\begin{tabular}{|l|l|l|l|l|l|l|l|}
\hline $\begin{array}{l}\text { Percentage } \\
\text { of } \\
\text { exposure } \\
\text { typically } \\
\text { hedged }\end{array}$ & $\begin{array}{l}\text { On-balance } \\
\text { Sheet } \\
\text { Transactions }\end{array}$ & $\begin{array}{l}\text { Off-balance } \\
\text { Sheet } \\
\text { Transactions }\end{array}$ & $\begin{array}{l}\text { Anticipated } \\
\text { Transactions } \\
1 \text { yr or less }\end{array}$ & $\begin{array}{l}\text { Anticipated } \\
\text { Transactions } \\
\text { Over 1 yr }\end{array}$ & $\begin{array}{l}\text { Economic/ } \\
\text { Competitive } \\
\text { Exposure }\end{array}$ & $\begin{array}{l}\text { Foreign } \\
\text { Repatriations }\end{array}$ & $\begin{array}{l}\text { Translation } \\
\text { Of Foreign } \\
\text { Accounts }\end{array}$ \\
\hline $\begin{array}{l}>\mathbf{2 5 \%} \\
\mathbf{2 5 \% - 5 0 \%} \\
\mathbf{5 0 \% - 7 5 \%}\end{array}$ & & & & & & \\
$\mathbf{7 5 \% -}$ & & & & & & \\
$\mathbf{1 0 0 \%}$ & & & & & \\
\hline
\end{tabular}

11. For each of the following exposures, which best describes your typical hedging horizon? (Please check the appropriate response for each column.)

\begin{tabular}{|l|l|l|l|l|l|}
\hline Hedging Horizon & $\begin{array}{l}\text { Contractual } \\
\text { Commitments }\end{array}$ & $\begin{array}{l}\text { Anticipated } \\
\text { Transactions }\end{array}$ & $\begin{array}{l}\text { Economic/ } \\
\text { Competitive } \\
\text { Exposure }\end{array}$ & $\begin{array}{l}\text { Foreign } \\
\text { Repatriations }\end{array}$ & $\begin{array}{l}\text { Translation } \\
\text { of Foreign } \\
\text { Accounts }\end{array}$ \\
\hline $\begin{array}{l}\text { Hedge shorter than the } \\
\text { maturity of the exposure }\end{array}$ & & & & & \\
\hline $\begin{array}{l}\text { Hedge the maturity of } \\
\text { the exposure }\end{array}$ & & & & \\
\hline $\begin{array}{l}\text { Hedge longer than the } \\
\text { maturity of the exposure }\end{array}$ & & & & & \\
\hline $\begin{array}{l}\text { Hedge to the end of the } \\
\text { current period (budget } \\
\text { period or fiscal year) }\end{array}$ & & & & & \\
\hline
\end{tabular}

12. How often does your market view of exchange rates cause you to...

(Please check the appropriate response for each column.)

Never Sometimes Frequently
a. Alter the timing of hedges
b. Alter the size of hedges
c. Actively take positions in currency derivatives

13. What percent of your total foreign currency derivatives (by face value of contacts) have the following original maturities: (Please enter the approximate percentage of currency hedging for each maturity.)

90 days or less

91 to 180 days

181 days to one year

One year to three years

Beyond three years 


\section{Interest Rate Exposure}

14. Which Statement(s) best describes the benchmark your firm uses for evaluating the management of the debt portfolio? (Circle all that apply.)

a. Our firm does not uses benchmark for the debt portfolio

b. The volatility of interest expense relative to a specified portfolio

c. Realized cost of funds relative to a market index (e.g. Libor)

d. Realized cost of funds relative to a portfolio with a specified duration

e. Realized cost of funds relative to a portfolio with a specified ratio of fixed to floating rate debt

f. Other benchmark (please describe)

\section{If your firm does not use interest rate derivatives, please skip ahead to Section IV.}

15a. How often does your firm transact in the interest rate derivatives market to... (Please check the appropriate column for each row. Choose 'Not Applicable' if a reason is not relevant to your firm.)
a. Swap from fixed rate to floating rate debt
b. Swap from floating rate to fixed rate debt
c. Fix in advance the rate (spread) on new debt
d. Reduce costs or lock-in rates based upon a market view

Not Applicable Never Sometimes Frequently

15b. How often does your market view of interest rates cause you to...

(Please check the appropriate response.)

\section{Never Sometimes Frequently}
a. Alter the timing of hedges
b. Alter the size of hedges
c. Actively take positions in interest rate derivatives 


\section{Option Contracts}

16a. Please indicate which of the following types of option contracts your firm has used in the past months for the indicated exposures.

(Please check marks in the appropriate columns for each type of option, leave blank if options are not used.)

\section{Types of Exposure \\ FX IR CM}

ANY
a. Standard European-style options
b. Standard American-style options
c. Average rate (price) options
d. Basket options (options on two or more prices)
e. Barrier options (knock-in/knock-out)
f. Contingent premium (options with deferred or conditional premiums)
g. Option combinations (i.e. collars, straddles, etc.)
h. Other

16b. If your firm does not use options, can you tell us why not?

\section{Control and Reporting Procedures}

17a. Does your firm have a documented policy with respect to the use of derivatives? (Please circle the appropriate response.)
a. Yes
b. No

17b. How frequently is derivatives activity reported to the Board of Directors?

(Please circle the appropriate response.)
a. Monthly
b. Quarterly
c. Annually
d. As needed/No set schedule
e. Other

18. What is the lowest rate counterparty with which you will enter a derivatives transaction? (Please check the appropriate rating for each maturity.)

a. Maturities 12 months or less

\section{AAA AA A BBB BBB Don't Know}

b. Maturities more than 12 months

19. How frequently do you value your derivatives portfolio?

(Please circle the appropriate answer.)
a. Daily
d. Quarterly
b. Weekly
e. Annually
c. Monthly
f. As needed/No set schedule

20. Rank your degree of reliance on each of the following for valuing your derivative positions. Please rank items; 1 - Most important; 3 - Least important; Use an " $X$ " if a method is not used at all.) 
a. Dealer that originated the transaction

b. Another dealer, consultant, or price vendor (e.g. Bloomberg)

c. Internal source (e.g. software, spreadsheet, etc.)

21. How do you evaluate the risk management function?

(Please circle the statement that best matches your practice.)
a. Reduced volatility relative to a benchmark
b. Increased profit (reduced costs) relative to a benchmark
c. Absolute profit/loss
d. Risk adjusted performance (profits or savings adjusted for volatility)

Thank you for completing the survey. Please mail it today in the enclosed postage-paid envelope. 


\section{Appendix B: Variable Definitions}

Summary of explanatory variables and a detailed description of the method of calculation.

Variable Name

Variable Description

BM Ratio of book to market value of the firm. Book value of common shareholders' equity is total assets less total liabilities less outstanding preferred stock (Compustat data items 6,181, and 130, respectively). Market value is closing share price times common shares outstanding at year-end 1997 (Compustat data items 199 and 25, respectively). The ratio is the average over $1995-1997 .{ }^{36}$

RD Ratio of RD (Compustat data item 46) to sales (Compustat item 12) for 1997.

SIZE Market value of the firm at fiscal year-end 1997. The sum of the market value of equity (Compustat data item 199 times Compustat data item 25), book value of longterm debt (Compustat data items 9 and 34), and book value of preferred stock (Compustat data item 130).

QUICK Quick ratio. Ratio of cash and short-term investments as of fiscal year-end 1997 (Compustat data item 1) to current liabilities as of fiscal year-end 1997 (Compustat data items 34, 70, 71, and 72). The ratio is the average over 1995-1997.

COV Interest coverage ratio. Ratio of pretax income for 1997 (Compustat data item 170) plus interest expense for 1997 (Compustat data item 15) to interest expense plus capitalized interest (Compustat data item 239) for 1997.

DE Debt-to-equity ratio. Ratio of book value of long-term debt as of the end of fiscal year 1997 (Compustat data items 34 plus 9) to SIZE. The ratio is the average over 1995-1997.

S\&P $\quad$ S\&P Bond rating (Compustat data item 280), numbered consecutively from 1 (AAA) to 24 (D) for 1997. ratings on noninterest bearing debt are set to missing.

\footnotetext{
${ }^{36}$ For two firms, we use two-year averages over 1996 and 1997 to calculate BM, QUICK, and DE because 1995 data are missing.
} 
Compensation variables are created separately for the CEO and CFO. The individual identified as the CEO or CFO is the one that was the CEO or CFO for the majority of fiscal $1997 .{ }^{37}$ The primary source of data is Execucomp. Missing items were supplemented with hand-collection of data from proxy statements and data from CRSP.

\section{DELTA and VEGA}

The CEO delta is the sum of the deltas for the exercisable and unexercisable options plus the delta of his shareholdings, which is defined as shares owned (Execucomp variable SHROWN) * $0.01 *$ end of fiscal year price (Execucomp variable PRCCF). The CEO vega is the sum of the vegas of the exercisable and unexercisable options. The vega of the shareholdings is assumed immaterial consistent with Coles, Daniel and Naveen (2003). We compute the delta and vega of the exercisable and unexercisable options separately. Estimates of the delta and convexity of a CEO's options are based on Black-Scholes (1973) formula for valuing European call options as modified to account for dividend payouts by Merton (1973) following the Core and Guay (1999) methodology.

Option value $=\left[\mathrm{Se}^{-\mathrm{dT}} \mathrm{N}(Z)-\mathrm{Xe}^{-\mathrm{rT}} \mathrm{N}\left(Z-\sigma \mathrm{T}^{(1 / 2)}\right)\right]$

where

$\mathrm{Z}=\left[\ln (\mathrm{S} / \mathrm{X})+\mathrm{T}\left(\mathrm{r}-\mathrm{d}+\sigma^{2} / 2\right)\right] / \sigma \mathrm{T}^{(1 / 2)}$

$\mathrm{N}=$ cumulative probability function for the normal distribution

$\mathrm{S}=$ The company's close stock price at fiscal year end 1997 (Execucomp variable PRCCF)

$\mathrm{X}=$ exercise price of the option ${ }^{38}$

$\sigma=$ The stock return volatility calculated over 60 months as used in Execucomp's Black-Scholes valuation of options (Execucomp variable BS VOLAT)

$\mathrm{r}=$ natural logarithm of the risk-free interest rate ${ }^{3 \overline{9}}$

$\mathrm{T}=$ time to maturity of the option in years ${ }^{40}$

$\mathrm{d}=$ natural logarithm of expected dividend yield for fiscal year 1997 (Execucomp variable BS_YIELD), which is the company's average dividend yield over the past 3 years.

The option delta, which is the sensitivity with respect to a $1 \%$ change in stock price is defined as:

$[\delta(\text { option value }) / \delta(\text { price })]^{*}($ price $/ 100)=\mathrm{e}^{-\mathrm{dT}} \mathrm{N}(Z) *($ price $/ 100)$

\footnotetext{
${ }^{37}$ When a firm has two different CEOs or CFOs during the year, we retain the one that had the longest duration. In one case, a new CFO started on July 1, 1997. We retained the CFO from the latter half of the year.

${ }^{38}$ Following Core and Guay, we compute the average exercise price in two steps. First, we divide the value the CEO would have realized at year end if he had exercised all of his vested and unvested (exercisable and unexercisable) options that had an exercise price below the market price (Execucomp variables INMONEX and INMONUN, respectively) by the number of vested and unvested options that the CEO held at year end (Execucomp variables UEXNUMEX and UEXNUMUN, respectively). Second, we subtract the quotients from the end of fiscal year price (PRCCF).

${ }^{39}$ Interest rate yields are the natural $\log$ of treasury bond yields from CRSP as quoted at the firm's fiscal year end. If T $=1$, $\mathrm{r}=$ the one-year bond yield; if $\mathrm{T}=2$ or $3, \mathrm{r}=$ the two-year bond yield; if $\mathrm{T}=4$ or $\mathrm{T}=5, \mathrm{r}=$ the five-year bond yield; if $6<=$ $\mathrm{T}<=8, \mathrm{r}=$ the seven-year bond yield; and if $\mathrm{T}=9$ or $\mathrm{T}=10, \mathrm{r}=$ the ten-year bond yield.

${ }^{40}$ We compute time to maturity in years from Execucomp data for each grant during 1997 assuming that the grant was made at the end of the firm's fiscal year. We take the average time to maturity of all grants during the year, equally weighted. We round to the nearest whole year. We use .7 of this maturity following Execucomp's convention. For exercisable options, we take the average time to maturity - three years. It is set $=1$, if that time $<0$. It is set $=6$, if the data are missing. For unexercisable options, we take the average time to maturity -1 year. It is set $=9$ if the data are missing. It is set $=1$ if $<0$. The max is set at 10 .
} 
The option vega, which is the sensitivity with respect to a $1 \%$ change in stock return volatility is defined as:

$[\delta(\text { option value }) / \delta(\text { volatility })]^{*} 0.01=\mathrm{e}^{-\mathrm{dT}} \mathrm{N}^{\prime}(\mathrm{Z}) \mathrm{ST}^{(1 / 2) *(0.01)}$

where $\mathrm{N}^{\prime}=$ normal density function

AGE Age of executive in years in 1997.

TENURE Number of years that the executive has been in his position as of December 31, $1997 .^{41}$

WITHCO Number of years that the executive has been with the company (Execucomp variable JOINED_C) as of December 31, 1997.

${ }^{41}$ If we were only able to find the year that an executive started in his position or with the company, the start month and day were set to July 1 . 